\title{
Personas con discapacidad y sus derechos frente a la pandemia de COVID-19: que nadie se quede atrás
}

\section{Introducción ${ }^{1}$}

Desde marzo de 2020, en América Latina y el Caribe se viene enfrentando una crisis sanitaria, social y económica debida a la enfermedad por coronavirus (COVID-19). Esta crisis ha profundizado las desigualdades que ya había en los países, ha revelado hasta qué punto están excluidos los grupos más vulnerables de la población y ha visibilizado la urgencia de incluir a las personas con discapacidad en las medidas de política pública que se tomen a corto, mediano y largo plazo (CEPAL, 2020a y 2020b; CEPAL/OPS, 2020).

En la región hay alrededor de 70 millones de personas con discapacidad: ellas constituyen uno de los grupos más excluidos de nuestra sociedad y se encuentran entre las más afectadas por esta pandemia. Antes de esta crisis sanitaria, las personas con discapacidad ya tenían menos probabilidades de participar en la comunidad y de acceder a la atención sanitaria, la educación y el empleo. Una proporción importante de ellas vive en la pobreza, está expuesta a tasas de violencia, abandono y abuso más elevadas que el resto de la población, y se encuentra entre los grupos más marginados de las comunidades cuando estas se enfrentan a una crisis.

Las personas con discapacidad resultan más afectadas debido a las barreras actitudinales, institucionales y del entorno, que se reproducen en la respuesta al COVID-19. Además, muchas personas con discapacidad tienen afecciones de salud preexistentes que las hacen más susceptibles de contraer el virus y de tener síntomas más graves al infectarse, lo que conduce a tasas elevadas de mortalidad.

En este contexto, se debe reforzar el mensaje internacional hacia los Estados para que todas las acciones que atañen a las personas con discapacidad se lleven a cabo desde el enfoque de los derechos, a fin de asegurar que nadie se quede atrás, ni tampoco fuera de las estrategias de mediano y largo plazo pospandemia. Se debe fortalecer la protección de los derechos de estas personas, considerando la Convención sobre los Derechos de las Personas con Discapacidad, la Agenda 2030 para el Desarrollo Sostenible y el Consenso de Montevideo sobre Población y Desarrollo. En esos instrumentos se coloca a las personas con discapacidad en el centro, y se entiende que estas son sujetos de derechos que deben participar en todas las etapas de las medidas que toman los Estados, desde la planificación y la implementación hasta la rendición de cuentas.

La información estadística actualizada sobre las personas con discapacidad escasea en la región, más aún cuando se requiere información asociada a cómo ha evolucionado el COVID-19 en este grupo de población. No se cuenta con datos desagregados por discapacidad, lo que dificulta los análisis y la toma de decisiones durante esta crisis y en las instancias posteriores de reactivación.
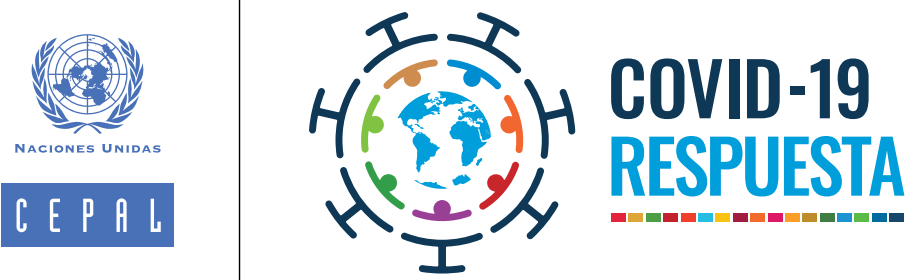

Introducción

A. Instrumentos internacionales en que se protegen los derechos de las personas con discapacidad en situaciones de riesgo humanitario

B. Panorama sociodemográfico de las personas con discapacidad en América Latina y el Caribe antes de la pandemia

C. Recomendaciones sobre las acciones de política pública

Bibliografía 
En el presente documento se ofrece un diagnóstico de la situación de las personas con discapacidad frente al impacto que el COVID-19 podría tener en ellas, tomando en consideración la estructura por edad y sexo, las afecciones de salud y los tipos de discapacidad que tienen, el acceso a infraestructura básica y el hacinamiento que hay en sus hogares, el acceso a las tecnologías de la información y las comunicaciones (TIC), la situación laboral y la educación. Por último, se presentan algunas acciones nacionales que se han puesto en marcha para disminuir el impacto de la pandemia y se plantean recomendaciones para enfrentar el devastador impacto social y económico del COVID-19 en las personas con discapacidad.

\section{A. Instrumentos internacionales en que se protegen los derechos de las personas con discapacidad en situaciones de riesgo humanitario}

En marzo de 2020 el virus SARS-CoV-2 llegó a América Latina y el Caribe. Varios países de la región se convirtieron en el epicentro de la pandemia y encabezan las estadísticas mundiales de casos. En un informe reciente de CEPAL/OPS (2020, pág.3) se indica que la pandemia "ha devenido en una inédita crisis económica y social y, si no se toman medidas urgentes, podría transformarse en una crisis alimentaria, humanitaria y política".

En diferentes foros regionales sobre el COVID-19, las personas con discapacidad han indicado que no están siendo consideradas en las estrategias que se están llevando a cabo para responder a la pandemia en sus países. Especialmente en el contexto actual de pandemia de COVID-19 por el que atraviesan la región y el mundo, se debe fortalecer la protección de los derechos de las personas con discapacidad, más aún cuando existe un instrumento internacional vinculante y otros instrumentos internacionales, mundiales y regionales en que se aboga en el mismo sentido.

En la Convención sobre los Derechos de las Personas con Discapacidad, la Agenda 2030 para el Desarrollo Sostenible y el Consenso de Montevideo sobre Población y Desarrollo se coloca a las personas con discapacidad en el centro y, por tanto, se señala que estas deben participar en todo el proceso de diseño y ejecución de las políticas públicas, así como en la rendición de cuentas.

En estos instrumentos se releva la importancia de que, en situaciones de emergencia, los Estados se preocupen de forma especial por las personas con discapacidad, indicaciones que se ajustan totalmente a lo que está ocurriendo hoy en día en el mundo en general y en América Latina y el Caribe en particular. En el artículo 11 de la Convención sobre los Derechos de las Personas con Discapacidad se señala que los Estados parte deberán adoptar "todas las medidas necesarias para garantizar la seguridad y la protección de las personas con discapacidad en situaciones de riesgo, incluidas situaciones de conflicto armado, emergencias humanitarias y desastres naturales" (Naciones Unidas, 2006, pág. 9). Por tanto, en esta situación de pandemia de COVID-19 que se vive en los países de la región, los Estados deben garantizar que se adopten todas las medidas necesarias para evitar que las personas con discapacidad se contagien del virus y, si ya se han contagiado, que cuenten con acceso expedito a los sistemas de salud necesarios para su atención. Además, deben implementar acciones de apoyo económico y social, pues esta crisis sanitaria ha golpeado con fuerza a todos los hogares y familias de la región, sobre todo a los más pobres y vulnerables. Sin embargo, las acciones dirigidas a los hogares que tienen personas con discapacidad deben ser más específicas, y adaptarse a la condición de discapacidad y a la severidad de esta.

Asimismo, en el artículo 25 de la Convención sobre los Derechos de las Personas con Discapacidad, que se refiere a la salud, se señala que "los Estados Partes reconocen que las personas con discapacidad tienen derecho a gozar del más alto nivel posible de salud sin discriminación por motivos de discapacidad", y se destaca la importancia de impedir "que se nieguen, de manera discriminatoria, servicios de salud o de atención de la salud o alimentos sólidos o líquidos por motivos de discapacidad" (Naciones Unidas, 2006, pág. 16). Esto último cobra fuerza en las instancias actuales, porque se han 
denunciado casos en que no se ha prestado atención o no se ha dado prioridad a las personas con discapacidad en el acceso a camas de alta complejidad. Hoy más que nunca se deben respetar estos derechos, pues ninguna persona con discapacidad debe quedar desatendida en esta situación sanitaria, y los Estados deben hacer todo lo posible por evitar que estas personas sean discriminadas. Por otra parte, en el artículo 28 de la Convención sobre los Derechos de las Personas con Discapacidad, que se refiere al nivel de vida adecuado y a la protección social, se refuerza la importancia de que los Estados redoblen las medidas y acciones para asegurar un acceso en condiciones de igualdad a los programas de protección social y para que las personas puedan gozar de ese derecho sin discriminación por motivos de discapacidad (Naciones Unidas, 2006, pág. 18). Los Estados deben adoptar las medidas pertinentes para proteger y promover el ejercicio de ese derecho. El Objetivo 3 de la Agenda 2030 va en esta misma línea, pues en él se indica que se debe garantizar una vida sana y promover el bienestar de todos a todas las edades. Si bien en la región se había avanzado en lo que atañe a estos aspectos, la pandemia es un punto de inflexión que exige que los Estados se preparen para las emergencias sanitarias, lo que incluye destinar recursos para que se haga un buen manejo de estas.

Contar con información adecuada sobre las personas con discapacidad siempre ha sido un gran reto en los países de la región. Las recomendaciones internacionales han ido en la línea de que se capte mejor la información en los censos de población, las encuestas específicas y los registros de personas con discapacidad, porque allí siempre se han presentado subenumeraciones. En los países ha sido un desafío elaborar estas mediciones desde el enfoque social de la discapacidad, como se sugiere en las recomendaciones de las Naciones Unidas, la Organización Mundial de la Salud (OMS) y el Grupo de Washington sobre Estadísticas de la Discapacidad. Estas limitaciones de los instrumentos estadísticos, que ya estaban presentes antes de la pandemia, se han hecho más evidentes con la crisis sanitaria: hasta ahora no hay información sobre el contagio según la situación de discapacidad, o el tipo y la severidad de esta. Algo similar ocurre con el número de fallecidos: no hay registro de cuántos de ellos eran personas con discapacidad. En el artículo 31 de la Convención sobre los Derechos de las Personas con Discapacidad, que trata sobre la recopilación de datos y estadísticas, se indica que los Estados parte deberán recopilar información adecuada, en particular datos estadísticos y de investigación, que les permita formular y aplicar políticas. Por tanto, urge que los Estados incorporen la situación de discapacidad de las personas contagiadas y fallecidas en sus mediciones sobre la pandemia, para tener más antecedentes sobre la manera en que ella afecta a este grupo de población.

En la meta 17.18 del Objetivo 17 de la Agenda 2030 se hace referencia a los datos, la supervisión y la rendición de cuentas, y se propone "aumentar significativamente la disponibilidad de datos oportunos, fiables y de gran calidad desglosados por ingresos, sexo, edad, raza, origen étnico, estatus migratorio, discapacidad, ubicación geográfica y otras características pertinentes en los contextos nacionales". En los países de la región se han hecho esfuerzos para avanzar en el cumplimiento de esta meta (CEPAL, 2019c), pero es evidente que no se ha logrado cumplirla en el ámbito de las personas con discapacidad, y menos aún en lo que respecta a la producción de datos estadísticos sobre estas personas en relación con el COVID-19. Hasta ahora, en los países no se ha sistematizado dicha información y, si esta existe, no todos pueden acceder a ella. Por tanto, no es posible hacer análisis sobre este tema que permitan diseñar acciones y tomar decisiones con un respaldo estadístico robusto.

Esta ausencia de datos referidos a las personas con discapacidad tiene diversos efectos. En lo que atañe directamente a la pandemia, se desconoce la morbilidad y la mortalidad en relación con estas personas, lo que impide tomar medidas específicas de prevención y de contención dirigidas a quienes cursan la enfermedad. La falta de datos actualizados respecto de las personas con discapacidad hace que sea difícil dar una respuesta eficiente y eficaz a las necesidades de esta población en contextos de crisis, y tampoco permite establecer acciones a mediano y largo plazo dirigidas a ella. Por lo tanto, urge contar con información actualizada en este ámbito.
Las personas con discapacidad no pueden quedarse atrás durante la pandemia de COVID-19, ni tampoco fuera de las estrategias de mediano y largo plazo pospandemia. 


\section{B. Panorama sociodemográfico de las personas con discapacidad en América Latina y el Caribe antes de la pandemia}

En América Latina y el Caribe viven alrededor de 70 millones de personas con discapacidad. Este grupo de población se encuentra en una situación muy vulnerable en cuanto al impacto sanitario y social de la pandemia (CEPAL, 2020a).

A lo largo de la historia, las personas con discapacidad han pertenecido a los grupos más desfavorecidos de la sociedad. De forma permanente han estado excluidas del acceso a recursos de todo tipo y se les ha negado el reconocimiento, además de que se les ha postergado la posibilidad de participar plenamente en la vida económica, social, política y cultural (CEPAL, 2019a, 2018a y 2013a).

En general, las personas con discapacidad presentan mayores porcentajes de pobreza, menores niveles de instrucción y menor inserción en el ámbito laboral. La menor participación de los niños, las niñas, los adolescentes y los y las jóvenes con discapacidad en la educación formal da como resultado bajos logros educativos. Esto, a su vez, es muy probable que afecte el acceso a un trabajo decente que permita obtener un ingreso justo y acceso a la protección social, sobre todo cuando se trata de personas con ciertos tipos de discapacidades que suponen un mayor grado de limitación (González y Stang, 2014; CEPAL, 2018a). Es frecuente que las personas con discapacidad enfrenten barreras de acceso a los recursos materiales, las instituciones, los espacios de participación, los bienes, los derechos o los servicios fundamentales para la vida social, y que no tengan control sobre las decisiones que les atañen (CEPAL, 2018b).

En un estudio reciente de la CEPAL sobre el COVID-19 y las personas con discapacidad, se reconoce que este grupo poblacional es diverso y es objeto de "discriminaciones múltiples y simultáneas debido a su situación socioeconómica, su género, edad, lugar de residencia, condición étnico-racial y estatus migratorio, entre otras" (CEPAL 2020a, pág. 1).

La relación entre discapacidad y pobreza es compleja e interdependiente, y hay evidencia de que es uno de los factores que explica la persistente exclusión de este grupo de personas. Esta relación se da en diversos canales y niveles; además, la discapacidad es causa y, a su vez, en gran medida, consecuencia de la pobreza (CEPAL, 2018b).

De acuerdo con la OMS (2011, pág. 12), "las personas con discapacidad presentan tasas más altas de pobreza que las personas sin discapacidad". Al respecto, en Meléndez (2019) se señala que "existe una suerte de vínculo bidireccional entre la pobreza y la discapacidad, pues la pobreza incrementa el riesgo de padecer alguna discapacidad y la discapacidad eleva el riesgo de estar dentro de la pobreza".

En el transcurso de las últimas dos décadas se han realizado varios estudios que revelan que uno de los principales problemas que enfrenta la población con discapacidad en la región es el desempleo y la marginación laboral que, por cierto, inciden en el hecho de que esta población se encuentre en situación de pobreza. Un alto porcentaje de las personas con discapacidad de América Latina están desempleadas o excluidas de la fuerza laboral: las diferencias de acceso al mercado de trabajo se materializan en una desigualdad que adquiere un carácter estructural (Stang, 2011). En el estudio de González y Stang (2014), que estaba basado en censos realizados a inicios de la década de 2010, se mostraba que el panorama no había variado significativamente. En los seis países analizados, la proporción de personas con discapacidad que pertenecían a la población económicamente activa (PEA) era menor que la de las personas sin discapacidad: las brechas desfavorables para la población con discapacidad iban del 15\% en el Brasil al 31\% en el Uruguay. Estos antecedentes reflejaban tanto desigualdad como incumplimiento de derechos, y además coincidían con la información disponible a nivel internacional, según la cual la participación de las personas con discapacidad en la fuerza de trabajo era muy inferior a la de las personas sin discapacidad (Naciones Unidas, 2009). Esto se suma a la falta de accesibilidad en la vía pública y en los lugares de trabajo, así como a la discriminación y la persistencia de estereotipos negativos que acentúan la baja inserción laboral de las personas con discapacidad (CEPAL, 2018b). 
En los países de la región se advierten situaciones muy similares a las que se observan en el resto del mundo respecto del acceso de las personas con discapacidad a los servicios de salud. Estas personas son particularmente vulnerables a las deficiencias que presentan algunos servicios, como la atención de salud primaria, la rehabilitación, y la asistencia y el apoyo. No todas las personas con discapacidad logran recibir la rehabilitación médica que necesitan, solo una proporción baja de ellas recibe los dispositivos auxiliares necesarios y, por cierto, no todas ellas acceden a los servicios de bienestar social. Tanto el costo del acceso a los servicios de salud como la ausencia de estos cerca de las áreas donde las personas con discapacidad residen llevan a que estas personas no accedan a los centros de salud (OMS, 2011).

Los antecedentes señalados permiten constatar que, antes de la pandemia, las personas con discapacidad ya estaban en situaciones de desventaja social y económica frente al resto de la población. Esas situaciones acentúan aún más el riesgo de contagio y las dificultades para enfrentar los problemas asociados con esta crisis.

La información que se analiza en este documento proviene de los censos de población de los países de la región. Esta fuente de información se ha elegido principalmente porque ofrece ventajas comparativas a la hora de hacer estudios sobre las personas con discapacidad, aunque en algunos casos las preguntas presenten ciertas limitaciones (CEPAL, 2019a). Entre las ventajas se encuentra el hecho de que el censo es la única fuente de datos con cobertura universal y, por tanto, si las preguntas que captan información sobre este tema están bien formuladas, permite estimar la prevalencia de la discapacidad en el país y la frecuencia de las diversas tipologías. El censo permite, además, desagregar la información a escalas geográficas menores, lo que es relevante para realizar intervenciones a nivel local. Contribuye a esto la posibilidad de hacer una amplia caracterización sociodemográfica de las personas con discapacidad mediante el cruce con otras variables. También es posible realizar una comparación internacional, si es que el uso de los conceptos, la estructura de las preguntas y las categorías de las respuestas son homogéneos (CEPAL, 2019a).

Si bien en esta década no se han realizado los censos de la ronda de 2010 en todos los países de la región, hay un número importante de estos (16) en que sí se han llevado a cabo y en 15 de ellos se han agregado preguntas para captar la discapacidad, lo que permite tener una noción de la cantidad de población que pertenecen a este grupo (véase el gráfico 1). Alrededor del 14\% de la población latinoamericana tiene algún tipo de discapacidad, lo que representa un grupo importante de la población regional². Los porcentajes más altos se observan en seis países (Argentina, Brasil, Costa Rica, Perú, República Dominicana y Uruguay), donde la población con discapacidad supera el 10\%; en Guatemala y Honduras, por su parte, se observan los porcentajes más bajos. Estos antecedentes sobre la proporción de personas con discapacidad indican que es necesario conocer sus características sociodemográficas, puesto que estas personas enfrentan enormes desafíos respecto de la accesibilidad a los espacios y el acceso a oportunidades de educación, salud y trabajo decente, entre otros, más aún en esta situación de crisis provocada por la pandemia de COVID-19 que se vive en la región.

La información censal más reciente permite realizar análisis más actualizados sobre la situación en que se encontraban las personas con discapacidad cuando el COVID-19 llegó a sus países, con el objetivo de identificar cuáles son los mayores efectos que la pandemia puede tener en ellas, dada su situación sociodemográfica.

En los últimos tres años se realizaron censos de población en cuatro países: Chile y el Perú, en 2017, y Guatemala y Colombia, en 2018. En Chile, no obstante, no se incluyeron preguntas sobre discapacidad, ya que se realizó un censo más acotado. Por tanto, se cuenta con información sobre las personas con discapacidad en el Perú, Guatemala y Colombia, aunque es importante tener en cuenta que, si bien en las preguntas incluidas en los censos de los tres países se considera el enfoque social de la discapacidad, hay ciertas diferencias debido a las cuales la comparabilidad entre ellos no es total. En el recuadro 1 se describe de qué manera se captó la información sobre discapacidad en los censos de estos tres países, así como las diferencias metodológicas que presentan y que inciden en el momento de comparar sus resultados.

Es importante tener cautela al agregar estos datos censales a nivel regional, pues los enfoques metodológicos que se utilizan en los países difieren entre sí, y solo en algunos casos se considera la gradualidad de la discapacidad. 
Gráfico 1

América Latina y el Caribe (15 países): proporción de personas con discapacidad, censos de la década de 2010 (En porcentajes)

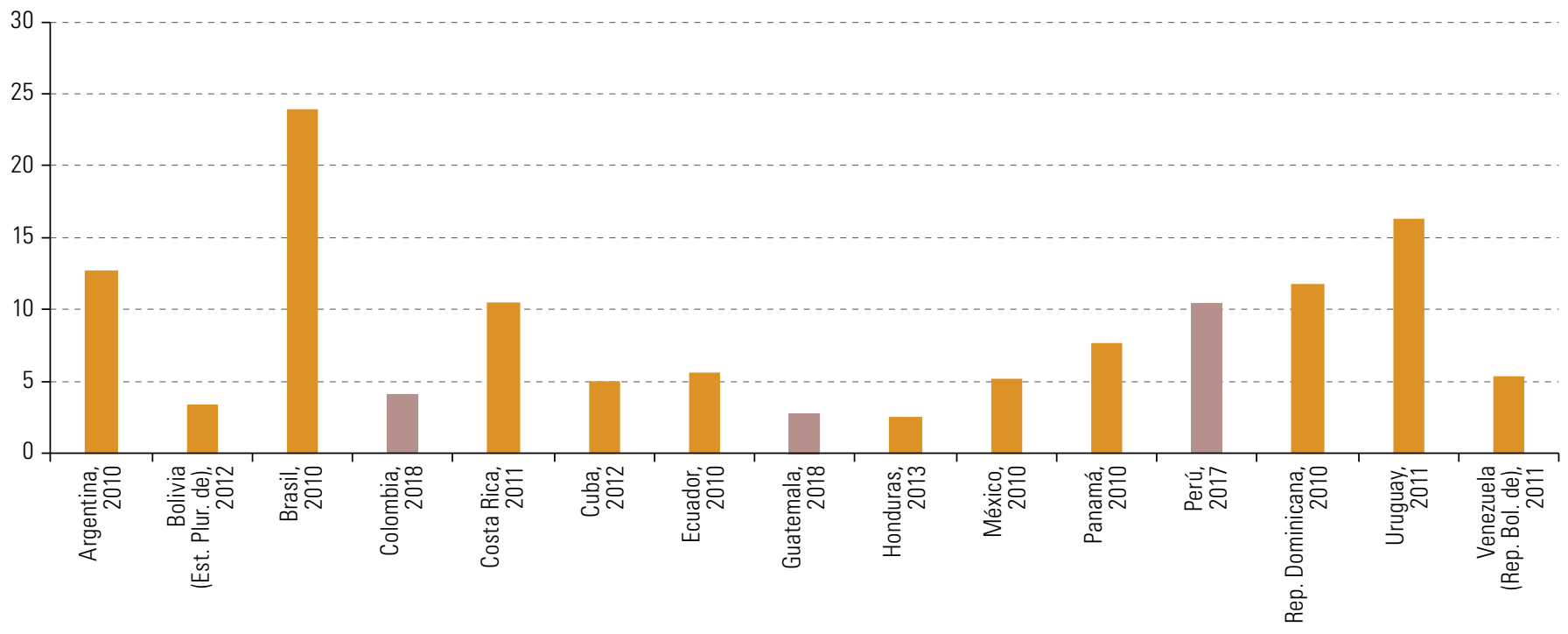

Fuente: Comisión Económica para América Latina y el Caribe (CEPAL), sobre la base de microdatos censales de los países correspondientes procesados con REDATAM.

Recuadro 1

La medición de la discapacidad en los censos de Colombia, Guatemala y el Perú

En las recomendaciones internacionales respecto de la inclusión de preguntas para medir la discapacidad en los censos se apunta a un set corto de estas en que se abarquen los siguientes seis dominios: i) la dificultad para ver aunque se usen anteojos; ii) la dificultad para oír aunque se use un dispositivo auditivo; iii) la dificultad para caminar o subir escaleras; iv) la dificultad para recordar o concentrarse; v) la dificultad para realizar tareas de cuidado personal (bañarse, vestirse), y vi) la dificultad para comunicarse en el idioma habitual. Como alternativas de respuesta se proponen las cuatro siguientes: i) no puede hacerlo; ii) tiene mucha dificultad; iii) tiene alguna dificultad, y iv) no tiene dificultad.

El Grupo de Washington sobre Estadísticas de la Discapacidad recomienda identificar como personas con discapacidad a quienes opten por las respuestas i) o ii) anteriores en al menos uno de los dominios. Esta información permite calcular la prevalencia y los diferenciales de participación a los efectos de presentar informes internacionales y hacer comparaciones entre los países (Grupo de Washington sobre Estadísticas de la Discapacidad, 2009 y 2017).

En el censo de Colombia se hicieron varias preguntas, pero estas estaban alejadas de las recomendaciones internacionales: en la primera, que era dicotómica, se indagaba acerca de los dominios recomendados, pero no se preguntaba sobre los apoyos técnicos que permitían mitigar la limitación, ya sea eliminándola por completo o haciendo que incidiera menos en las actividades de la vida diaria. Si las personas respondían afirmativamente a esta pregunta, se pasaba a la segunda, que incluía nueve dominios, entre ellos, los de oír y ver, pero sin preguntar por el apoyo de los audífonos y los lentes o anteojos, respectivamente. Por tanto, en las alternativas de respuesta i), ii) y iii) señaladas en el primer párrafo habría una sobreenumeración. La pregunta siguiente también funcionaba a modo de filtro y en ella se indagaba cuál de los dominios afectaba más a la persona en su desempeño diario: de los nueve dominios, el empadronado solo debía seleccionar uno. A continuación se preguntaba qué había ocasionado la dificultad en el dominio que se había seleccionado en la pregunta anterior y, por último, se indagaba por los apoyos técnicos que se utilizaban para hacer frente a la dificultad. Estas preguntas extensas recargaban el cuestionario, se alejaban del enfoque social de la discapacidad — pese a que en la segunda se intentaba integrarlo- y era muy probable que, al revisar los resultados, se observaran problemas de sub- o sobreestimación, así como una mayor cantidad de personas que no respondieran.

En el censo de Guatemala, en tanto, se utilizaron los seis dominios recomendados y las cuatro respuestas alternativas que permitían establecer el grado de limitación, pero se aplicó un filtro de edad, ya que las preguntas se realizaron con referencia a las personas de 4 años o más. Es importante detenerse en este punto. Si bien las preguntas propuestas por 
el Grupo de Washington sobre Estadísticas de la Discapacidad permiten captar mejor la información cuando se trata de la población de 5 años y más, pues a esa edad hay ciertas limitaciones que ya son detectables, algunas limitaciones pueden estar presentes desde el nacimiento y, por tanto, para no perder esos datos, es conveniente no aplicar un filtro de edad, teniendo claro que hay ciertas limitaciones cognitivas o psicosociales que solo se harán evidentes a edades más avanzadas.

En el censo del Perú se utilizaron los seis dominios recomendados con una formulación muy cercana a la de las recomendaciones, pero en las respuestas no se incorporó la gradualidad de la limitación. Por tanto, la pregunta se ajustaba al enfoque social, pero la dicotomía de la respuesta (sí o no) incidía de manera negativa en la captación de los datos sobre las personas con discapacidad y podría llevar a que se sobreestimara esa población, pues era posible que algunas personas que hubieran escogido la alternativa de respuesta iii) (algo de dificultad), al no contar con esa alternativa, respondieran afirmativamente.

En conclusión, el censo de Guatemala es el que más se ajusta a las recomendaciones internacionales. En el del Perú se hace un buen intento en cuanto a la formulación de las preguntas, pero no así en las categorías de respuesta. En el de Colombia se complejiza la manera de preguntar porque se agregan muchas preguntas filtro y, por tanto, desde el punto de vista metodológico ese censo se aleja un tanto de las recomendaciones propuestas a nivel internacional. Con todo, en Guatemala y Colombia fue posible establecer las categorías i) no puede hacerlo y ii) tiene mucha dificultad como las que definen el número de personas con discapacidad. En el Perú, la categoría "sí" en al menos un dominio determina el número de personas que tienen esa condición.

Fuente: Comisión Económica para América Latina y el Caribe (CEPAL), "Aspectos conceptuales de los censos de población y vivienda: desafíos para la definición de contenidos incluyentes en la ronda 2020", serie Seminarios y Conferencias, № 94 (LC/TS.2019/67), Santiago, 2019; Grupo de Washington sobre Estadísticas de la Discapacidad, The Washington Group Short Set on Functioning: Question Specifications, Washington, D.C., 23 de octubre de 2017 [en línea] https://www.washingtongroup-disability.com/fileadmin/uploads/wg/Documents/ Events/17/WG-Document-4-The-Washington-Group-Short-Set-on-Functioning-Question-Specifications.pdf; y Understanding and Interpreting Disability as Measured using the WG Short Set of Questions, Washington, D.C., 20 de abril de 2009 [en línea] http://www.cdc.gov/nchs/ data/washington_group/meeting8/interpreting_disability.pdf.

\section{Estructura por edad y sexo}

En el cuadro 1 se muestra la proporción de personas con discapacidad en los tres países que se analizaron. La proporción más alta se observa en el Perú, donde alrededor de un 10\% de la población presenta algún tipo de discapacidad. En Colombia, el porcentaje bordea el 4\% y, en Guatemala, no supera el 3\%. En el Perú y Guatemala hay una mayor proporción de personas con discapacidad en las áreas urbanas que en las rurales; en Colombia, en cambio, se presenta la situación inversa y la proporción es levemente mayor en el campo.

\section{Cuadro 1}

Colombia, Guatemala y Perú: proporción de personas con discapacidad según área de residencia, 2017 y 2018

(En porcentajes)

\begin{tabular}{lccc}
\hline & Total del país & Urbano & Rural \\
\hline Perú, 2017 & 10,4 & 10,7 & 8,8 \\
\hline Guatemala, 2018 & 2,8 & 3,0 & 2,5 \\
Colombia, 2018 & 4,1 & 3,8 & 4,9 \\
\hline
\end{tabular}

Fuente: Elaboración propia sobre la base de microdatos censales de los países correspondientes procesados con REDATAM.

Con respecto a la estructura por edad y sexo de las personas con discapacidad, en las pirámides de población se observa una mayor proporción en las edades centrales y superiores (véase el gráfico 2). En el caso de Colombia, menos del 10,6\% de todas las personas con discapacidad son menores de 18 años, mientras que el $46 \%$ tiene 60 años o más. En Guatemala, el 15\% de las personas con discapacidad tiene menos de 18 años y el 44\% tiene 60 años o más. Las personas con discapacidad en el Perú son sobre todo 
personas mayores: el $40 \%$ corresponde a esas edades, mientras que el $14 \%$ tiene menos de 18 años. Se constata que la estructura por edad de las personas con discapacidad se diferencia bastante de la que corresponde a las personas sin discapacidad: la de estas últimas es más bien joven, con una pirámide que tiene un ancho mayor en la base y en las edades de 18 a 29 años.

\section{Gráfico 2}

Colombia, Guatemala y Perú: proporción de personas con y sin discapacidad en el total de la población por grupos de edad y sexo, censos de la década de 2010

(En porcentajes)

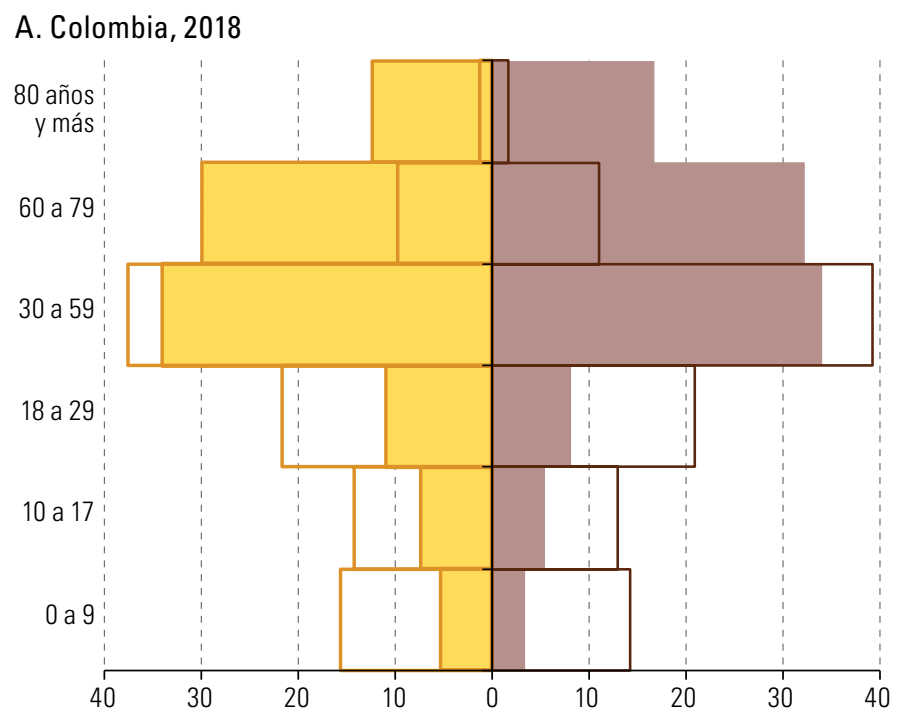

\section{B. Guatemala, 2018}

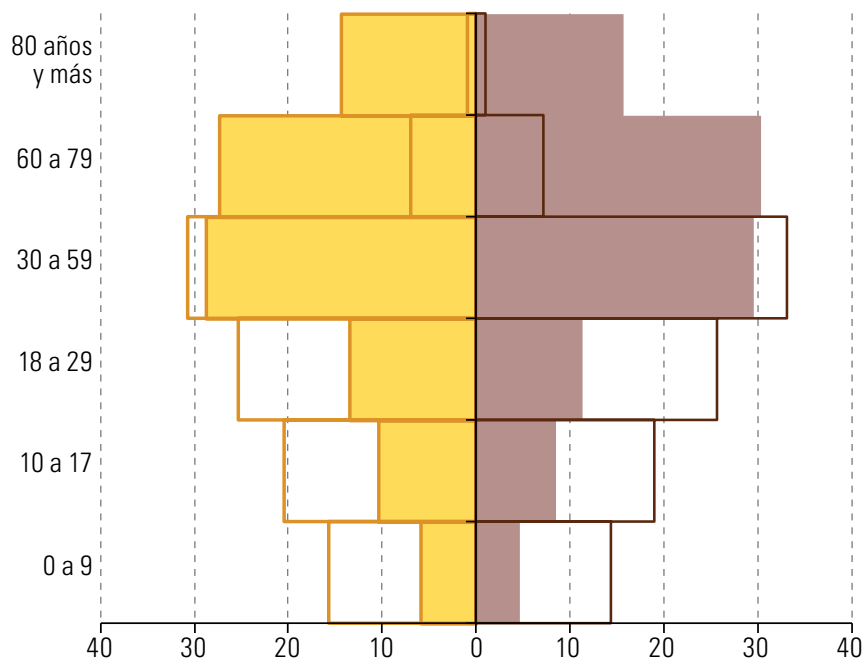

\section{Perú, 2017}

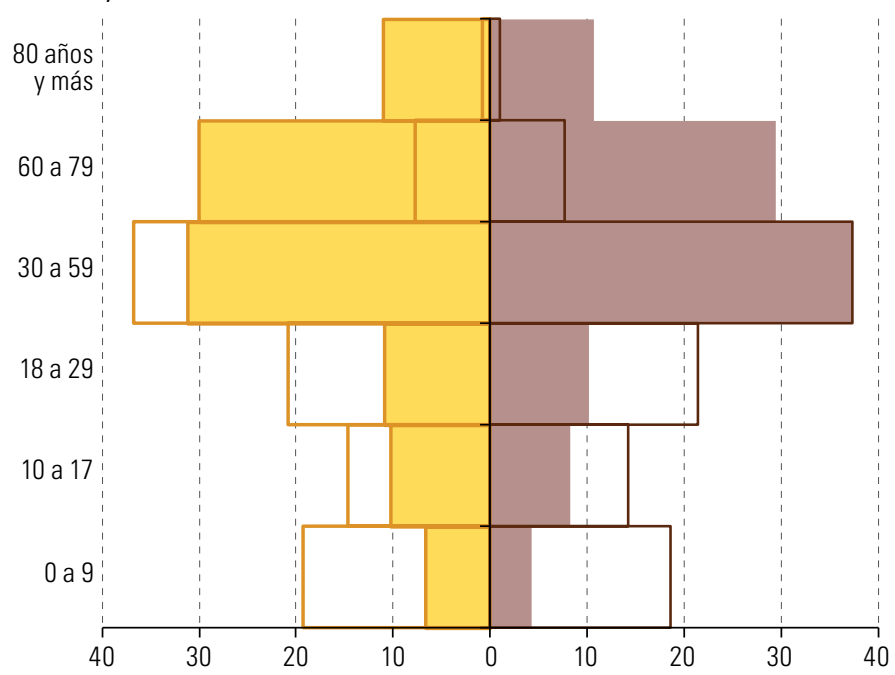

Hombres con discapacidad

Mujeres con discapacidad

Hombres sin discapacidad

Mujeres sin discapacidad

Fuente: Comisión Económica para América Latina y el Caribe (CEPAL), sobre la base de microdatos censales de los países correspondientes procesados con REDATAM. 
El hecho de que las personas con discapacidad tengan una estructura demográfica más envejecida sugiere que este grupo poblacional tendría comorbilidades propias de las edades más avanzadas, que podrían o no tener relación con el tipo de discapacidad que presentaran, pero que ocasionarían casos más graves de COVID-19 si estas personas contrajeran la infección, ya que el virus exacerba los problemas de salud existentes y aumenta la probabilidad de morir en las edades más avanzadas (OMS, 2020b).

Se advierte que hay una mayor prevalencia de discapacidad entre las mujeres: la relación de masculinidad es de 87 hombres por cada 100 mujeres en Colombia, 92,2 por cada 100 en Guatemala y 76 por cada 100 en el Perú. Sin embargo, al diferenciar por grupos de edad, se observa que el predominio femenino se acentúa aún más en las edades más avanzadas, sobre todo a los 80 años y más, franja en que la relación de masculinidad es de 64, 85 y 77 hombres por cada 100 mujeres en los tres países mencionados, respectivamente. Este predominio femenino se advierte en general en estudios anteriores realizados con datos censales de otros países de la región. González y Stang (2014, pág. 83) mencionan que "una característica sobresaliente es que las personas con al menos una discapacidad presentan sistemáticamente relaciones de masculinidad inferiores a 100, es decir, hay una mayor presencia femenina". También señalan que, en un estudio reciente, "se indicaba que las mujeres registraban una tasa de prevalencia de discapacidad más alta que los hombres, y que esta situación ocurriría en más de la mitad de los países de la región". Y agregan que, también en ese estudio, "se apuntaba que esto se tornaba más evidente a partir de los 60 años, dado que la mayor esperanza de vida de las mujeres aumentaría la posibilidad de tener una discapacidad asociada a una enfermedad crónica o a un accidente en etapas avanzadas de la vida".

Es fundamental que, en el momento de llevar a cabo acciones dirigidas a las personas con discapacidad frente a la pandemia, se considere tanto la perspectiva de género como el tipo de discapacidad, puesto que estos aspectos determinarán qué resguardos se deberán tomar para prevenir el contagio y proteger a las personas que hayan contraído la enfermedad

Como ya se indicó, en los tres países en estudio se consideraron en parte los seis dominios que el Grupo de Washington sobre Estadísticas de la Discapacidad recomendaba incluir. En algunos casos incluso se incorporaron más dominios. Por eso es posible analizar y hacer comparaciones en varios de ellos. En el gráfico 3 se presenta la proporción de personas con discapacidad según el tipo de limitación. Se advierte que, en los tres países, el mayor porcentaje es el que corresponde a las personas que tienen limitaciones para ver aunque usen anteojos. En efecto, el 48\%, el 27,7\% y el 24\% de las personas con discapacidad del Perú, Guatemala y Colombia, respectivamente, declaran tener esta limitación. La segunda mayor proporción corresponde a las limitaciones para moverse o caminar (alrededor del 20\% en los tres países). En tercer lugar se ubica la dificultad para oír aunque se use un audífono: el 14,7\% de las personas con discapacidad de Guatemala, el 13,2\% de las del Perú y el 9,4\% de las de Colombia dicen tener esta limitación, aunque en este último país ella ocupa el cuarto lugar. Otro dominio común en los tres países es la dificultad para relacionarse con los demás: el mayor porcentaje de personas con esta limitación se encuentra en Guatemala (14,4\%), mientras que, en Colombia y el Perú, el porcentaje es muy similar (alrededor del 5,5\%). Respecto de las limitaciones para entender o comprender, el 11,7\% de las personas con discapacidad de Guatemala declara tener esta limitación, mientras que, en Colombia y el Perú, ese porcentaje es del 9,7\% y el 8,2\%, respectivamente. En el Perú y Colombia se indagó acerca de la dificultad del habla, y la proporción de personas con discapacidad que presenta esta limitación es inferior al 10\% (5\% en el Perú y $7 \%$ en Colombia).

Respecto a las limitaciones para realizar tareas de cuidado personal, como comer, vestirse o agarrar cosas, los porcentajes son cercanos al 8\% en Colombia y Guatemala: este dominio es relevante porque es un indicador indirecto del número y la proporción de personas que necesitan apoyo para realizar las actividades cotidianas y, por ende, que requieren cuidados diarios. En Colombia se indagó acerca de un dominio que se aleja de las recomendaciones de los organismos internacionales, pues se refiere más bien a una afección médica, a saber, las deficiencias respiratorias y cardíacas; sin embargo, en el contexto actual de pandemia de un virus que ataca principalmente al sistema respiratorio y cardíaco, es interesante considerar esta categoría, que representa un 8,8\% de las personas con discapacidad de dicho país.
Las personas con discapacidad tienen una estructura poblacional más envejecida que podría llevar a que presentaran casos más complejos de COVID-19. 
Gráfico 3

Colombia, Guatemala y Perú: proporción de personas con discapacidad según el tipo de limitación, censos de la década de 2010

(En porcentajes)

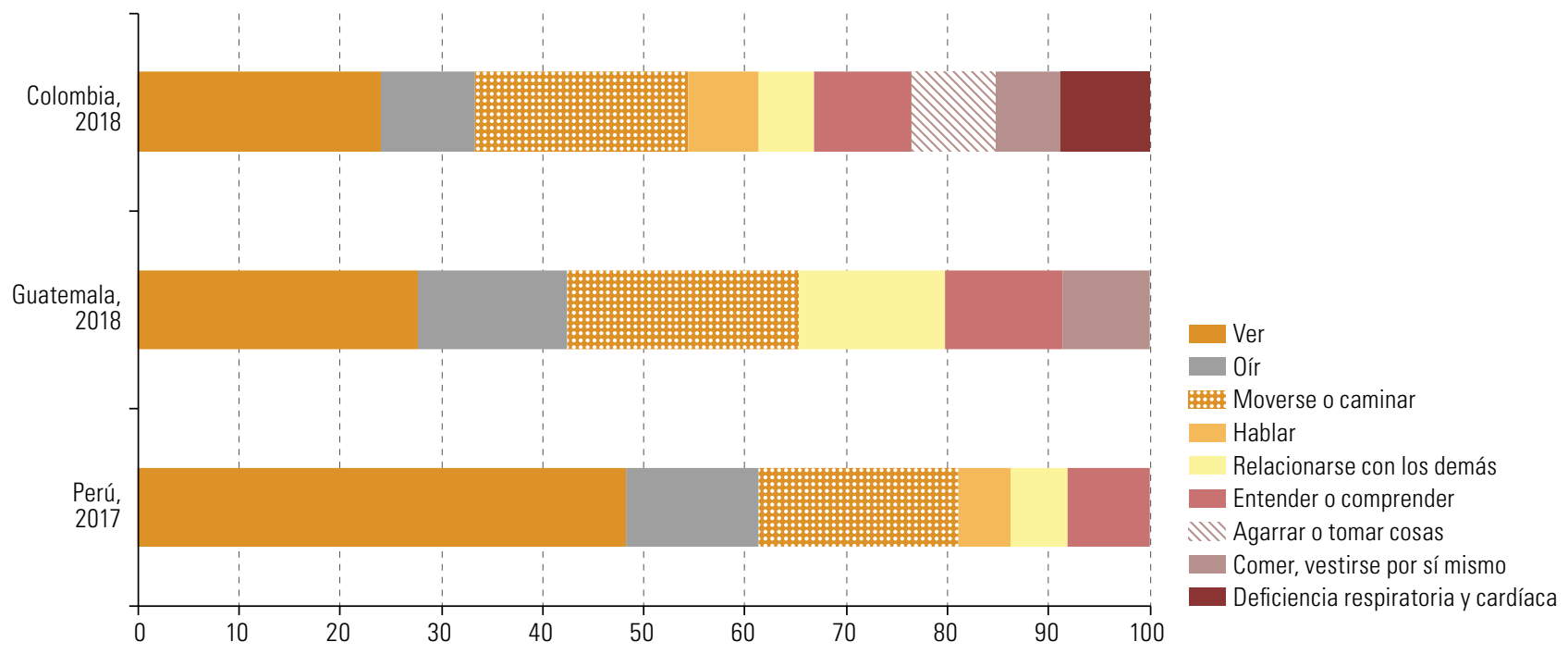

Fuente: Comisión Económica para América Latina y el Caribe (CEPAL), sobre la base de microdatos censales de los países correspondientes procesados con REDATAM.

Hay diferencias significativas en lo que respecta al tipo de limitaciones que presentan las personas con discapacidad según el sexo. Por ejemplo, las limitaciones para ver aunque se usen anteojos y las dificultades para moverse y caminar son más prevalentes entre las mujeres, mientras que, entre los hombres, la dificultad para oír aunque se usen audífonos es la más prevalente, seguida de las limitaciones para moverse y caminar.

La OMS considera que las personas con discapacidad pueden tener un mayor riesgo de contraer COVID-19 debido a diferentes factores, que se intensificarían si la prevalencia de cierta limitación fuera mayor. Por ejemplo, la aplicación de algunas medidas básicas de higiene, como el lavado de manos, puede ser más difícil para las personas que tienen limitaciones para agarrar o tomar objetos, o que tienen dificultades para frotarse bien las manos; por otra parte, las personas que tienen limitaciones para moverse o caminar, deben usar silla de ruedas u otro apoyo técnico y no cuentan con servicios higiénicos o lavamanos físicamente accesibles para ellos tendrán más obstáculos para implementar las medidas de higiene recomendadas.

Otro factor importante es la dificultad de las personas con discapacidad a la hora de mantener el distanciamiento físico si necesitan apoyos adicionales para realizar las actividades de la vida diaria o si se encuentran institucionalizadas. Asimismo, las personas ciegas o con limitaciones de visión que tienen la necesidad de tocar objetos para obtener información del entorno o que deben apoyarse físicamente en espacios de uso frecuente correrán más riesgo de infectarse y contraer el virus. Por cierto, sin importar cuál sea el tipo de limitación, todos los obstáculos que las personas con discapacidad puedan tener para acceder a la información de salud pública y, en particular, a la información sobre el COVID-19 aumentarán el riesgo de contagio (OMS, 2020b).

Entre las personas con discapacidad hay algunas que presentan comorbilidades o trastornos de salud subyacentes y, en esos casos, pueden correr más riesgo de presentar casos más graves de COVID-19 si contraen la infección. Esto se debe a que el virus exacerba los problemas de salud existentes, sobre todo los relacionados con la función respiratoria, el sistema inmunitario, las cardiopatías o la diabetes (OMS, 2020b). Pero, además, las personas con discapacidad podrían tener obstáculos para acceder a la atención de salud, en parte debido a la mayor demanda de estos servicios en el contexto de la pandemia o a que se dé prioridad a otros grupos de población por diversas razones. Es en este entorno que, 
desde que se inició la pandemia y particularmente cuando esta se intensificó en algunos países de la región, tanto el Comité sobre los Derechos de las Personas con Discapacidad como la Enviada Especial del Secretario General sobre la Discapacidad y la Accesibilidad han emitido diversos comunicados en que se exhorta a los Estados a tomar todas las medidas apropiadas para garantizar el acceso de las personas con discapacidad a los servicios de salud y para proporcionarles la misma variedad, calidad y nivel de atención médica que se brinda a otras personas, incluidos los servicios de salud mental. Junto con ello se debe considerar que las personas con discapacidad infectadas por el coronavirus siempre tendrán derecho a ser tratadas con dignidad, a tomar decisiones con autonomía, a que se respete su voluntad y sus preferencias, a que se solicite su consentimiento libre e informado, y a que se proteja la privacidad de sus datos personales. Esto se debe hacer teniendo en cuenta especialmente los artículos 10, 25 y 28 de la Convención sobre los Derechos de las Personas con Discapacidad, la Agenda 2030 para el Desarrollo Sostenible, en particular el Objetivo 3 sobre salud y bienestar, y varias medidas prioritarias del Consenso de Montevideo sobre Población y Desarrollo.

\section{Hogares y familias que tienen personas con discapacidad}

Una forma diferente de aproximarse al análisis de la discapacidad es salir del ámbito del individuo y centrarse en los hogares y las familias donde las personas con discapacidad están insertas, puesto que es desde ahí que interactúan, ya sea dentro del propio grupo familiar o con la sociedad. Es importante considerar también las situaciones que ocurren en el hogar cuando uno o varios de sus miembros tienen algún tipo de discapacidad, pues el apoyo y el cuidado que se brinden dependerán del tipo de hogar o familia. Asimismo, no hay que perder de vista las diferencias de género existentes, puesto que adquieren relevancia a escala familiar: los roles de los hombres y las mujeres no son iguales a lo largo del ciclo vital de las personas y tampoco en el hogar o la familia. La carga del cuidado y el apoyo que se brinda a las personas con discapacidad dentro del hogar por lo general recae en las mujeres, ya sean las madres, las hijas o las parejas de dichas personas. Y, en este contexto de crisis sanitaria, la carga que suponen el cuidado y las tareas del hogar puede aumentar significativamente entre las mujeres.

En el cuadro 2 se constata que la mayor proporción de hogares que tienen al menos una persona con discapacidad se presenta en el Perú (26\%), mientras que, en Guatemala, la proporción es del 14\% y, en Colombia, del 10\%. Si bien en estos dos últimos países la proporción no supera el 15\% del total de los hogares, se aprecia que el impacto de la discapacidad es mayor a escala del hogar que a escala individual.

\section{Cuadro 2}

Colombia, Guatemala y Perú: proporción de hogares que tienen personas con discapacidad, censos de la década de 2010

(En porcentajes)

\begin{tabular}{ll}
\hline Guatemala, 2018 & 14,2 \\
\hline Colombia, 2018 & 10,4 \\
\hline Perú, 2017 & 26,3 \\
\hline
\end{tabular}

Fuente: Comisión Económica para América Latina y el Caribe (CEPAL), sobre la base de microdatos censales de los países correspondientes procesados con REDATAM.

Cuando se considera la situación de discapacidad desde la perspectiva de los hogares y las familias, el grupo de población integrado por las personas con discapacidad tiene un impacto aún mayor en la sociedad, pues el hogar y la familia es el espacio donde transcurre gran parte de la vida de las personas (Pérez, 2016). Existe una gran variedad de arreglos familiares: las personas pueden optar por vivir solas, en parejas sin hijos, en hogares monoparentales, en uniones consensuales o en uniones homoparentales (Arriagada, 2007). Sin embargo, no es tan claro que las personas con discapacidad tengan la misma libertad para tomar esas decisiones, pese a que tienen derecho a vivir una vida independiente. 
En los hogares que tienen personas con discapacidad hay más demanda de apoyo y cuidado durante la crisis sanitaria, y un recrudecimiento de la carga que estas tareas suponen para las mujeres.
Conocer la estructura de los hogares y las familias de las personas con y sin discapacidad permite determinar qué demandas específicas surgen en estos arreglos familiares cuando hay personas con discapacidad y así considerar políticas sociales específicas ${ }^{3}$. En el gráfico 4 se presenta la distribución relativa del arreglo familiar de los hogares que tienen y no tienen personas con discapacidad en los tres países que se han incluido en este análisis. Hay varias similitudes y algunas diferencias entre ambos tipos de hogares. En primer lugar, independientemente de que haya o no haya personas con discapacidad, priman los hogares integrados por familias nucleares biparentales. No obstante, esa proporción es mayor entre los hogares sin personas con discapacidad: el 53\% en Guatemala, y el 43\% en Colombia y el Perú. Entre los hogares que tienen personas con discapacidad, la proporción que representa esa categoría es menor, y la de las familias extendidas y biparentales con cónyuge y parientes ocupa el segundo lugar. Esas dos categorías representan más de la mitad de los hogares en que hay personas con discapacidad: el 63\% en Guatemala, el 52\% en Colombia y el $53 \%$ en el Perú. Esto indica que las personas con discapacidad residen en familias nucleares y extendidas debido al apoyo y el cuidado que esas personas necesitan en las actividades de la vida diaria. Sin embargo, aunque los hogares unipersonales tienen una mayor representación entre los hogares sin personas con discapacidad, una información muy importante que se desprende del gráfico es que alrededor del 10\% de los hogares que tienen personas con discapacidad son de ese tipo.

Gráfico 4

Colombia, Guatemala y Perú: estructura de los hogares que tienen y no tienen personas con discapacidad, censos de la década de 2010

(En porcentajes)

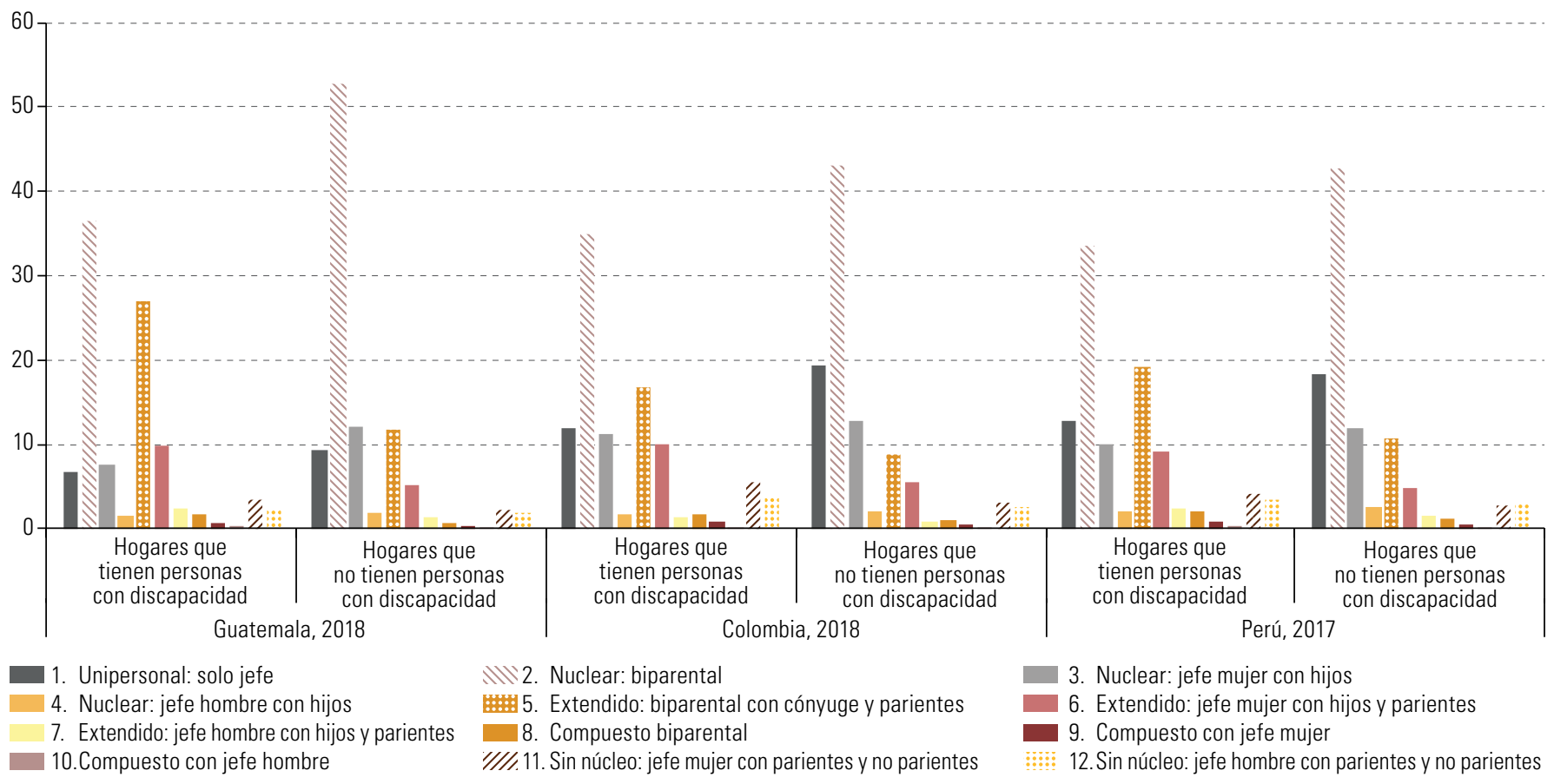

Fuente: Comisión Económica para América Latina y el Caribe (CEPAL), sobre la base de microdatos censales de los países correspondientes procesados con REDATAM.

La tipología de la estructura del hogar se basa en las características de la estructura de parentesco de los miembros de un hogar respecto de quien se declara jefe de este. Se establecen dos grandes tipos de unidades: hogares no familiares y familias. Entre los hogares no familiares se contemplan los hogares unipersonales y los que no tienen núcleo conyugal o vínculo paterno o materno, con o sin otros familiares. Entre las familias, en tanto, se incluyen las familias nucleares (solo miembros nucleares), extendidas (con presencia de otros parientes) y compuestas (con presencia de no parientes). Cada una de estas estructuras puede ser, a su vez, monoparental o biparental. 
En este contexto de crisis sanitaria, y con las medidas de confinamiento físico que se han implementado en los países para frenar la transmisión del virus, las personas con discapacidad y, particularmente, las que viven solas, pueden enfrentarse a situaciones de vulneración de derechos (CEPAL, 2020a). El acceso a los bienes y servicios esenciales que permiten mantener el bienestar puede verse interrumpido; esto es crítico sobre todo en el caso de los servicios de salud, rehabilitación y cuidados, pero también en el de los medicamentos, los pañales, los dispositivos de asistencia y los alimentos especiales, entre otros insumos (CEPAL, 2020a). Además, las relaciones de cuidado y la continuidad de este pueden verse suspendidas, y las redes de apoyo se debilitan o truncan debido a las cuarentenas totales impuestas en los países. Si alguna persona con discapacidad llega a contagiarse y a tener síntomas graves de la enfermedad, necesitará apoyo y cuidados: si no cuenta con tecnologías accesibles para comunicarse con los amigos o parientes, este apoyo puede retrasarse o no llegar en el momento en que lo necesiten.

Las mujeres son las que están estrechamente relacionadas con los cuidados y, en el caso de los hogares donde hay una persona con discapacidad que demanda cuidados diarios, son sobre todo ellas las que se encargan de brindarlos. Antes de la pandemia, estos cuidados se podían distribuir entre arreglos formales (centros educativos y de cuidado, centros de cuidado de personas en situación de dependencia, trabajo doméstico remunerado) e informales (apoyo de familiares y vecinas o vecinos, entre otros). Sin embargo, durante la pandemia y debido a las medidas de confinamiento y distanciamiento físico, estos arreglos se han reducido o se ha prescindido de ellos, lo que ha generado una mayor presión en las mujeres que prestan cuidados y ha incrementado de forma exponencial el trabajo que estos suponen, con una distribución desigual de la carga, que recae principalmente sobre las mujeres (CEPAL, 2020c).

En términos económicos y de cuidados, los hogares que tienen personas con discapacidad están sometidos a presiones mayores. En estos hogares hay más gastos de salud, rehabilitación, educación, y compra y mantenimiento de dispositivos de asistencia, así como de medicamentos y transporte (CEPAL, 2020a). Por otra parte, a los efectos de satisfacer las necesidades de cuidado que se comentaron en el párrafo anterior, algún miembro del hogar puede verse obligado a abandonar su trabajo remunerado y, en general, las que se retiran del mercado laboral son las mujeres. Esto incide en los ingresos del hogar, que ya están afectados por la crisis económica que se vive en los países de la región, lo que puede agravar las situaciones de pobreza si los Estados no implementan mecanismos de apoyo para cubrir o subvencionar los costos y las necesidades de estos hogares (CEPAL, 2020a).

\section{Hacinamiento y acceso a servicios básicos}

Desde que se inició la pandemia, las recomendaciones de la OMS y de los diferentes Ministerios de Salud de los países han estado referidas principalmente a que las personas se laven las manos de forma frecuente con agua y jabón, mantengan un distanciamiento físico de al menos 1 o 2 metros con los demás, eviten tocarse los ojos, la nariz y la boca, y utilicen mascarilla cuando estén en espacios públicos abiertos o cerrados.

Para cumplir estas medidas de prevención, la población debe tener acceso a agua potable en su vivienda, pues el lavado de manos debe ser frecuente y se deben lavar y desinfectar los alimentos $u$ otras cosas que ingresan al hogar. Por tanto, el acceso a agua potable se vuelve una necesidad primordial y, si bien siempre lo ha sido, en este contexto se intensifica aún más. En lo que respecta a las personas con discapacidad, estas deben contar con dicho acceso siempre dentro de la vivienda, y el baño o el lavamanos no debe presentar barreras físicas de accesibilidad.

En el Primer informe regional sobre la implementación del Consenso de Montevideo sobre Población y Desarrollo (CEPAL, 2019b) y en el Informe de avance cuatrienal sobre el progreso y los desafíos regionales de la Agenda 2030 para el Desarrollo Sostenible en América Latina y el Caribe (CEPAL, 2019c) se indica que el acceso a agua potable ha aumentado en la mayoría de los países, y que en ellos se han realizado esfuerzos importantes para aumentar la cobertura; sin embargo, esa labor ha sido insuficiente, pues continúan existiendo brechas entre las áreas urbanas y rurales. Con todo, a la fecha en que se elaboraron esos informes, más del $90 \%$ de la población utilizaba fuentes mejoradas de abastecimiento de agua potable. 
En los tres países que se analizaron se advierte que prácticamente no existen diferencias de acceso entre las personas con y sin discapacidad. Sí se constatan diferencias entre las áreas urbanas y las rurales, lo que significa que las personas con discapacidad de las primeras tienen más acceso a agua potable que las de las segundas. En efecto, en el gráfico 5 se observa que hay brechas importantes, en Colombia, mientras que el 5,6\% de las personas con discapacidad no cuentan con acceso a agua potable en las áreas urbanas, este porcentaje llega a casi el 38\% en las áreas rurales. En Guatemala, el 25\% de las personas con discapacidad no tienen acceso a agua potable dentro de sus viviendas en las áreas urbanas, en tanto que este porcentaje llega al $61 \%$ entre las personas con discapacidad de las áreas rurales. En el Perú, alrededor del 10\% de las personas con discapacidad no accede a agua potable dentro de la vivienda en el ámbito urbano, y este porcentaje alcanza el 28\% en las áreas rurales.

\section{Gráfico 5}

Colombia, Guatemala y Perú: proporción de población sin acceso a agua potable dentro de la vivienda según condición de discapacidad y área de residencia, censos de la década de 2010

\section{(En porcentajes)}

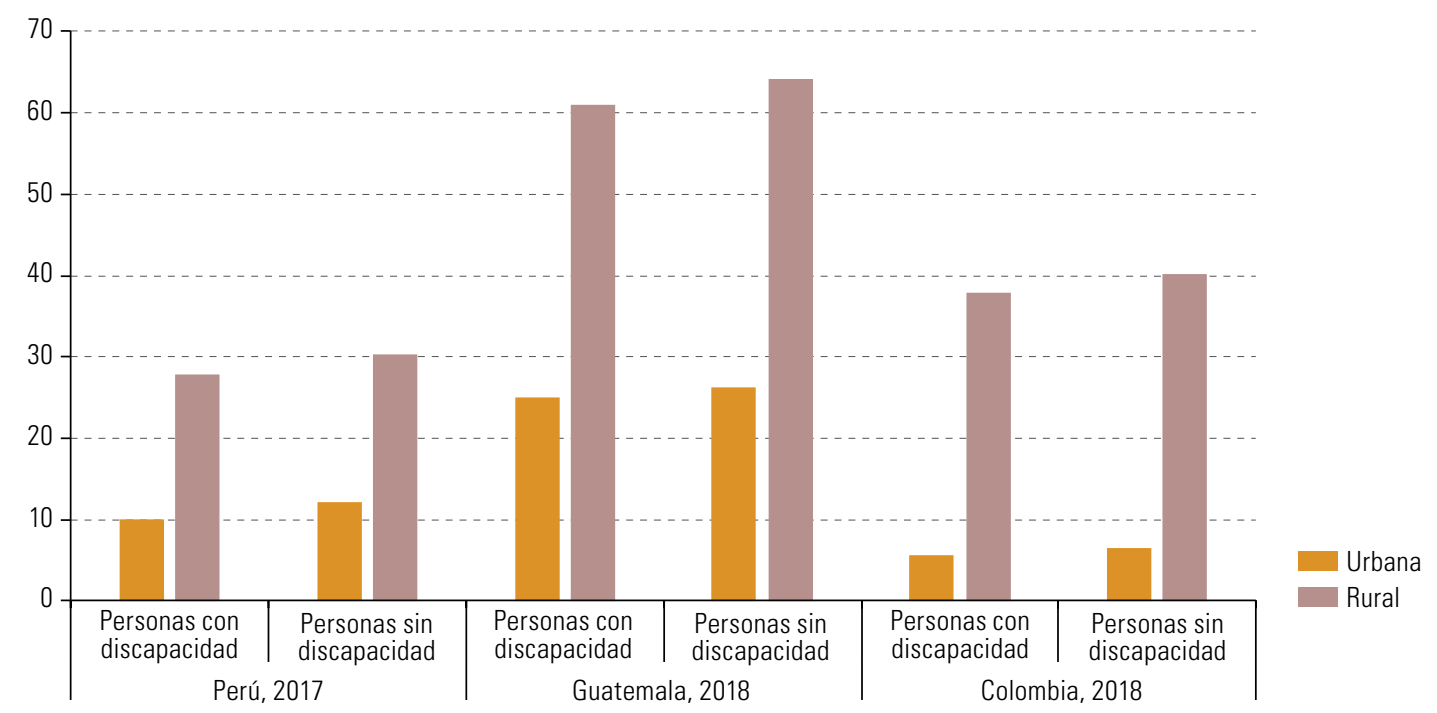

Fuente: Comisión Económica para América Latina y el Caribe (CEPAL), sobre la base de microdatos censales de los países correspondientes procesados con REDATAM.

Si bien estas cifras indican que prácticamente no hay diferencias de acceso a agua potable entre las personas con y sin discapacidad, es necesario considerar que, cuando no hay acceso dentro de la vivienda, las primeras tienen más dificultades para poner en práctica las recomendaciones respecto del lavado de manos frecuente y la limpieza y desinfección de sus hogares y alimentos, pues tienen más barreras para acceder a otras alternativas que les permitan conseguir el agua potable que necesitan. En un informe de las Naciones Unidas sobre el Objetivo 6 (garantizar la disponibilidad y la gestión sostenible del agua y el saneamiento para todos), se indica que las personas sin acceso a agua potable tendrán más dificultades para preservar su salud y bienestar, ya que la probabilidad de que se elimine por completo el COVID-19 es baja si no se cuenta con acceso a agua potable, y entonces, por ejemplo, los efectos en las personas con discapacidad serían considerablemente más graves en los contextos urbanos sin agua potable ya que es en las ciudades donde se ha dado con mayor intensidad la transmisión de contagios.

En un informe reciente de la CEPAL (2019b, pág. 185) se indica que, en la región, "se constata que el servicio con menor cobertura es el saneamiento básico", aunque también existen brechas entre las áreas urbanas y las rurales. En las áreas urbanas, menos del 70\% de los hogares tienen acceso a saneamiento y, en las áreas rurales, el porcentaje desciende al 53\% (CEPAL, 2019b). 
Respecto del acceso a saneamiento dentro de la vivienda, las tendencias son similares en los tres países en cuanto a que prácticamente no hay brechas de acceso entre las personas con y sin discapacidad (véase el gráfico 6). Colombia presenta la menor proporción de población sin acceso a este servicio: menos del 10\% de las personas se encuentra en esta situación. En Guatemala, por su parte, esta proporción aumenta al 48\% y, en el Perú, es de alrededor del 33\%. En estos agregados nacionales se observan brechas muy importantes entre las áreas urbanas y las rurales. Alrededor del 30\% de la población colombiana no tiene acceso a saneamiento en las áreas rurales, mientras que, en las urbanas, el porcentaje solo llega al 2,5\%. La proporción de población sin acceso en las áreas rurales de Guatemala es mayor (más del 72\%), aunque, en las áreas urbanas, ese porcentaje es del 25\%. En el Perú, el porcentaje supera el $85 \%$ en las áreas rurales y se ubica en alrededor del $20 \%$ en las áreas urbanas.

\section{Gráfico 6}

Colombia, Guatemala y Perú: proporción de población sin acceso a saneamiento dentro de la vivienda según condición de discapacidad y área de residencia, censos de la década de 2010

(En porcentajes)

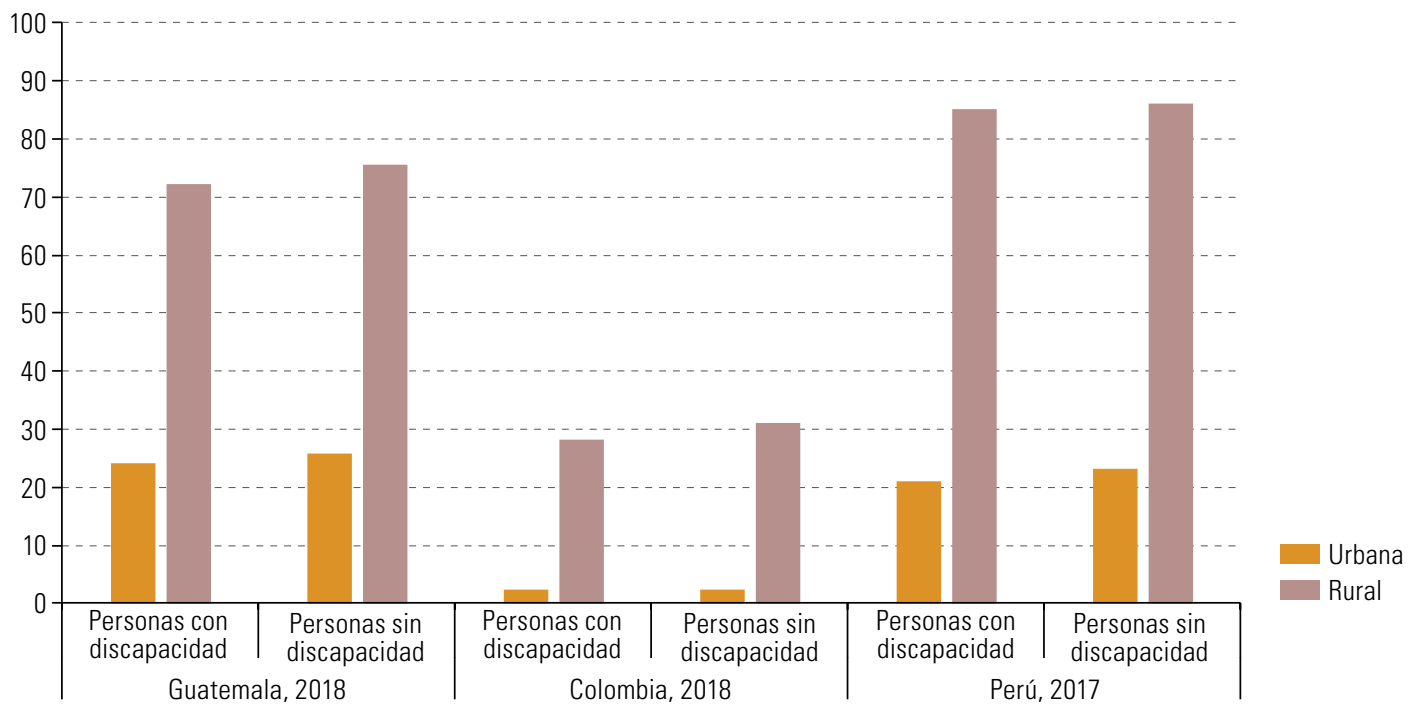

Fuente: Comisión Económica para América Latina y el Caribe (CEPAL), sobre la base de microdatos censales de los países correspondientes procesados con REDATAM.

La importancia de contar con una cobertura elevada de saneamiento tanto en las áreas urbanas como en las rurales se debe a que "el saneamiento se considera como uno de los usos inherentes al agua y el acceso a este no solo es fundamental para la dignidad humana, sino también para proteger la calidad de los recursos hídricos" (CEPAL, 2019b, pág. 185; Bautista, 2013). En el caso específico de las personas con discapacidad respecto del COVID-19, contar con acceso a saneamiento permite que haya más higiene en los lugares donde residen. El hecho de que las aguas servidas no se traten y estén contaminadas hace más difícil mantener un ambiente limpio e higienizado que ayude a protegerse del contagio.

Tanto el acceso al agua potable como el saneamiento son derechos humanos básicos. Bautista (2013) indica que se debe considerar que el agua y el saneamiento son derechos en sí mismos (derecho humano al agua y al saneamiento), y también medios esenciales para garantizar todos los derechos humanos, especialmente el derecho a la vivienda y a la salud. En este contexto, en el artículo 28 de la Convención sobre los Derechos de las Personas con Discapacidad, artículo que se refiere al nivel de vida adecuado y a la protección social, se establece que los Estados parte deben "asegurar el acceso en condiciones de igualdad de las personas con discapacidad a servicios de agua potable y su acceso a servicios, dispositivos y asistencia de otra índole adecuados a precios asequibles para atender las necesidades relacionadas con su discapacidad" (Naciones Unidas, 2006, pág. 18). Por tanto, los Estados deben garantizar los servicios básicos esenciales, y estos deben ser accesibles para las personas con discapacidad, 
Si en los hogares de las personas con discapacidad se cuenta con acceso a servicios básicos (agua y saneamiento) y hay un bajo nivel de hacinamiento, el riesgo de contagio tiende a disminuir. en igualdad de condiciones con las demás personas. Así, por ejemplo, a las personas con discapacidad se les debe facilitar el acceso a agua corriente y al lavado de manos, sobre todo en entornos informales.

En el seguimiento del Objetivo 6 de la Agenda 2030, objetivo que se refiere a garantizar la disponibilidad y la gestión sostenible del agua y el saneamiento para todos, se indica que, en el contexto de esta pandemia, se ha puesto de manifiesto "la importancia vital del saneamiento, la higiene y un acceso adecuado a agua limpia para prevenir y contener las enfermedades" (Naciones Unidas, 2020f). De esta manera, se establece que "la disponibilidad y el acceso a los servicios de agua, saneamiento e higiene (WASH) es fundamental para luchar contra el virus y preservar la salud y el bienestar de millones de personas".

El nivel de hacinamiento que hay en los hogares es otra variable que completa la tríada de factores sociodemográficos que aumentan la probabilidad de que el coronavirus se contagie y se propague ${ }^{4}$. Esto se debe a que, cuanto mayor es el hacinamiento, mayor es la dificultad para cumplir con las medidas recomendadas, como el distanciamiento físico y el autoaislamiento. Esto ha quedado en evidencia a medida que la pandemia ha ido avanzando en la región, ya que dicho avance se ha observado sobre todo en los aglomerados metropolitanos más grandes, que presentan áreas con déficits urbanos más graves

En los hogares que tienen personas con discapacidad, el hacinamiento es una barrera a la hora de aplicar las medidas de prevención que se deben tomar para evitar contagiarse de COVID-19. Para las personas con discapacidad no es fácil mantener el distanciamiento físico, puesto que presentan distintos grados de dependencia y, por tanto, necesitan de personas que les brinden apoyo. Además, hay ocasiones en que, dada su situación de pobreza, deben compartir habitación con varios otros miembros del hogar. Esto puede llevar a que aumente la probabilidad de contagio, pues si algún miembro de ese hogar es portador del virus y no puede tomar medidas de aislamiento físico dentro de él, aumentará la probabilidad de que todo el grupo familiar se contagie.

En el gráfico 7 se muestra la situación de hacinamiento de los hogares que tienen y no tienen personas con discapacidad. En él se advierte que hay un mayor porcentaje de hogares con hacinamiento entre las personas con discapacidad. En Guatemala, la mitad de los hogares que tienen personas con discapacidad presenta hacinamiento (51\%); en el Perú, este porcentaje es del 21\%, y, en Colombia, del 16\%. Si bien el hacinamiento es mayor en las áreas rurales, la proporción de hogares que tienen personas con discapacidad y presentan hacinamiento en las áreas urbanas es elevada, sobre todo si esto se analiza a la luz de la situación de crisis sanitaria que se vive actualmente.

Gráfico 7

Colombia, Guatemala y Perú: proporción de hogares con hacinamiento según situación de discapacidad y área de residencia, censos de la década de 2010

(En porcentajes)

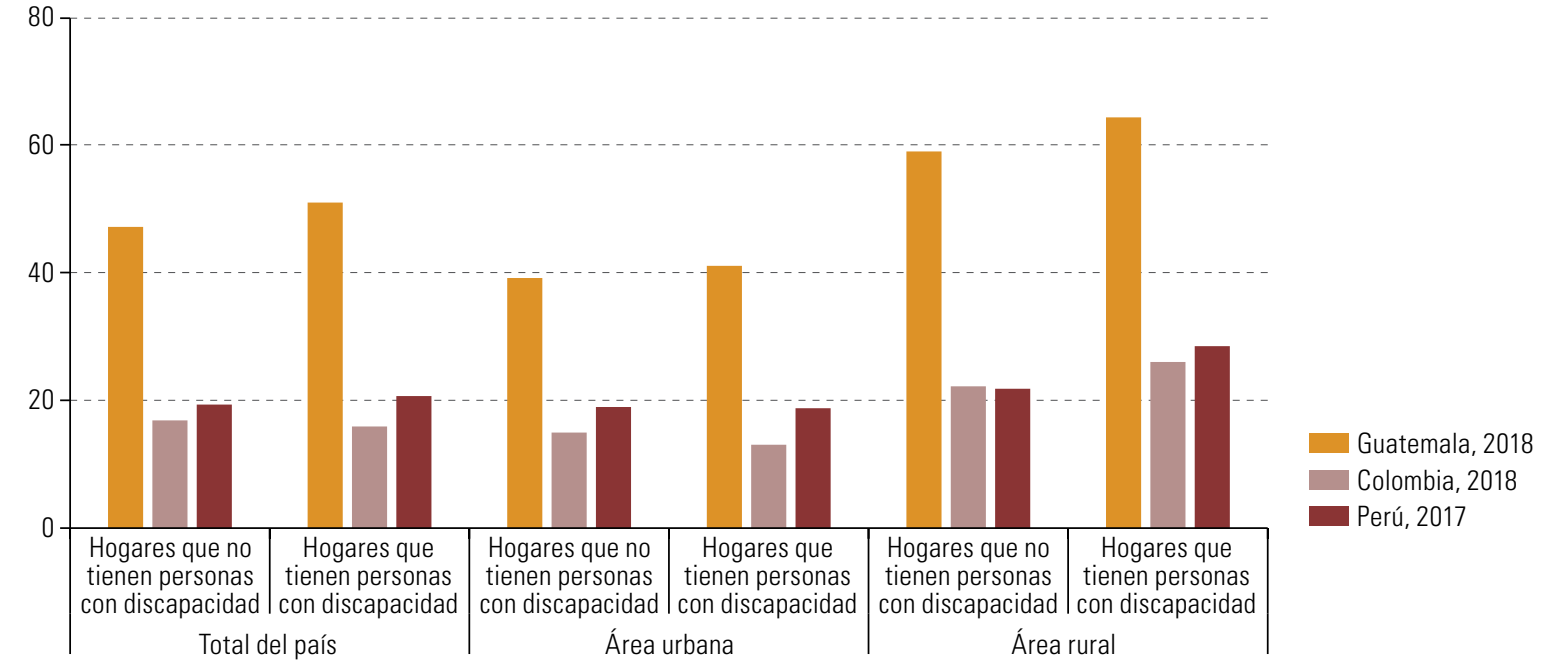

Fuente: Comisión Económica para América Latina y el Caribe (CEPAL), sobre la base de microdatos censales de los países correspondientes procesados con REDATAM. 
Es muy relevante que los organismos de salud y los encargados de tomar medidas para detener el avance del COVID-19 en los países de la región consideren la situación de hacinamiento que viven las personas con discapacidad a diario, pues este problema no solo tiene que ver con el hecho de que duerman más de 2,5 personas en un dormitorio. En las instancias de cuarentena y confinamiento obligatorio, las personas que residen en estos hogares se reúnen todas en estos pequeños lugares durante todo el día, sin espacios para la privacidad y sin horas o momentos de respiro para las cuidadoras o las personas que brindan apoyo a las personas con discapacidad. Una situación asociada al hacinamiento que se ha puesto de relieve en estos tiempos es la mayor exposición de las mujeres con discapacidad a la violencia doméstica, el abuso y el maltrato de todo tipo, así como la sobrecarga de cuidados dentro del hogar (Naciones Unidas, 2020b). En el recuadro 2 se hace referencia a este tema y se señalan algunas medidas que los Estados deberían implementar para paliar esta situación tan compleja.

Recuadro 2

Personas con discapacidad que sufren violencia durante la pandemia de COVID-19: el derecho a la protección y a vivir en ambientes libres de violencia

Existe evidencia de que las personas con discapacidad corren un mayor riesgo de sufrir violencia, en particular cuando están recluidas en sus hogares o en establecimientos de larga estadía. En general, entre las mujeres y las niñas con discapacidad se registra una mayor cantidad de episodios de violencia sexual, doméstica, de género y de pareja. El grado de violencia del que son objeto las niñas y las mujeres con discapacidad es más alto que el que afecta al resto de las mujeres y también a los hombres con discapacidad

En ausencia de datos sobre discapacidad y violencia de género en el contexto del COVID-19, se considera información obtenida en circunstancias similares anteriores en que las personas con discapacidad estuvieron particularmente en riesgo. Durante la pandemia actual se ha señalado que la violencia doméstica hacia las niñas y las mujeres ha aumentado; por lo tanto, se concluye que esto también está ocurriendo con las mujeres y las niñas con discapacidad.

Para las personas con discapacidad es muy difícil denunciar algún hecho de violencia, ya que hay barreras de acceso a los servicios y la asistencia en materia de violencia doméstica. En muchos casos, dichas personas no están incluidas en esos servicios y, en otros, no se cuenta con apoyos técnicos para que todos puedan acceder a ellos. A modo de ejemplo, en las líneas telefónicas de denuncia de varios países no se ofrecen servicios de interpretación para las personas sordas o ciegas, y los refugios y servicios de emergencia no están preparados para atender las necesidades de las personas con discapacidad.

Si bien en varios países se han realizado esfuerzos y se han emitido directrices para que los servicios encargados llamen por teléfono a las personas con discapacidad durante esta crisis y se comuniquen con ellas en persona cuando las medidas de confinamiento se levanten, aún queda mucho por hacer al respecto para cumplir con los artículos de la Convención sobre los Derechos de las Personas con Discapacidad relativos a este tema y para que los Estados garanticen que las personas con discapacidad vivan en un mundo sin violencia y maltrato.

Las siguientes son algunas medidas que la Oficina del Alto Comisionado de las Naciones Unidas para los Derechos Humanos (ACNUDH) recomienda que los Estados adopten en este ámbito:

- Asegurar que los mecanismos de denuncia, las líneas telefónicas de urgencia, los refugios de emergencia y otras formas de asistencia incluyan a las personas con discapacidad y sean accesibles para ellas

- Monitorear la situación de las personas con discapacidad, en particular de las que viven aisladas, mediante el contacto proactivo, incluso a través de redes comunitarias y voluntarias

- Concientizar y proporcionar capacitación sobre el riesgo de violencia que corren las personas con discapacidad, en particular las mujeres y las niñas, y promover la creación de redes de apoyo, lo que incluye fomentar el apoyo entre pares.

Fuente: Oficina del Alto Comisionado de las Naciones Unidas para los Derechos Humanos (ACNUDH), "COVID-19 y los derechos de las personas con discapacidad: directrices", Ginebra, 2020 [en línea] https://www.ohchr.org/Documents/Issues/Disability/COVID-19_and_ The_Rights_of_Persons_with_Disabilities_SP.pdf. 
Otro problema que el hacinamiento ocasiona en los hogares, particularmente en los que hay personas con discapacidad, es la dificultad para adoptar medidas si una persona se enferma de COVID-19, puesto que no es fácil establecer espacios seguros para quienes habitan en el hogar y cuesta mucho limitar al mínimo la interacción con el resto de los miembros o con las personas que brindan apoyo o asistencia. Por tanto, urge que los Estados tomen medidas para apoyar a las personas con discapacidad si se contagian y deben pasar la enfermedad en casa, pues, en general, en las opciones de residencia sanitaria no se contemplan las necesidades de las personas con discapacidad, por ejemplo, los apoyos o la asistencia.

\section{Acceso a luz eléctrica en los hogares}

En general, el acceso a luz eléctrica es uno de los indicadores que presenta los valores más altos en la región, aunque las brechas entre las áreas urbanas y las rurales siguen estando presentes. En un estudio reciente de la CEPAL se indica que "el acceso a energía eléctrica alcanza una media superior al $98 \%$ en el área urbana, mientras que en el área rural el valor es levemente superior al 85\%" (CEPAL, 2019b, pág. 182).

El seguimiento del Objetivo 7 de la Agenda 2030, objetivo que se refiere a garantizar el acceso a una energía asequible, fiable, sostenible y moderna para todos en el contexto de la pandemia, se destaca que "la falta de acceso a la energía puede obstaculizar los esfuerzos por contener la COVID-19 en muchas partes del mundo" (Naciones Unidas, 2020f). En el informe se detalla que "los servicios energéticos son clave para prevenir las enfermedades y luchar contra la pandemia". El hecho de que las comunidades y los hogares no cuenten con acceso a energía eléctrica podría aumentar aún más la crisis sanitaria y reducir significativamente la velocidad de la recuperación mundial.

Contar con acceso a la energía es importante durante la emergencia provocada por el COVID-19. En las personas con discapacidad esto se torna vital, ya que en varios casos necesitan apoyos técnicos que funcionan con energía eléctrica. Por tanto, es necesario que estén conectadas durante esta emergencia sanitaria.

En el gráfico 8 se constata que entre las personas con y sin discapacidad prácticamente no hay brechas en cuanto al acceso a la energía eléctrica. En los tres países que se analizan se observa que el porcentaje de población con discapacidad que no tiene acceso a este servicio básico es bastante similar al de la población sin discapacidad.

\section{Gráfico 8}

Colombia, Guatemala y Perú: proporción de población sin acceso a energía eléctrica según condición de discapacidad y área de residencia, censos de la década de 2010

(En porcentajes)

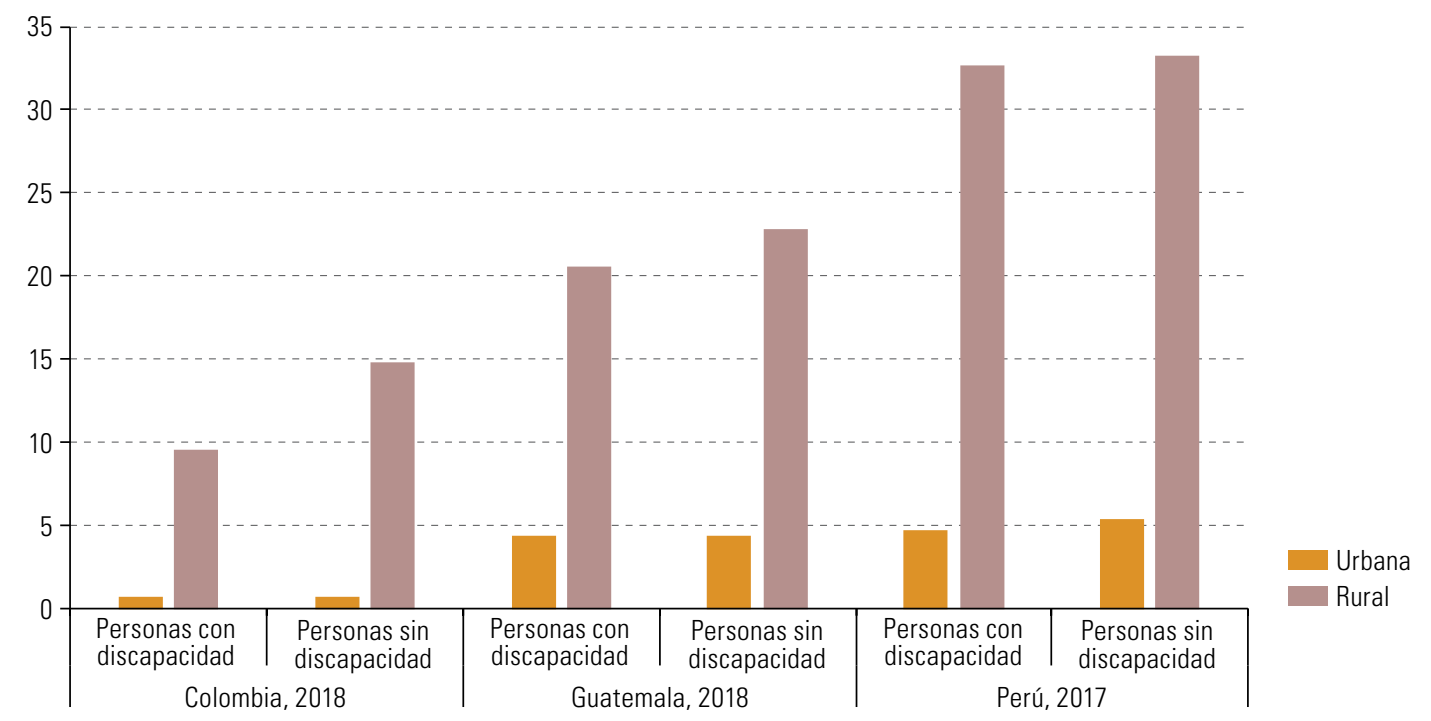

Fuente: Comisión Económica para América Latina y el Caribe (CEPAL), sobre la base de microdatos censales de los países correspondientes procesados con REDATAM. 
Entre las recomendaciones que realizan tanto la OMS como los organismos nacionales que brindan apoyo a las personas con discapacidad se encuentran algunas medidas que se deben considerar si estas se contagian de COVID-19. Una de ellas se relaciona con la importancia de que estas personas dispongan de vías de comunicación diversas y seguras con sus redes de apoyo, mediante teléfono celular, teléfono fijo, WhatsApp, redes sociales o correo electrónico, para que las personas amigas o familiares puedan brindarles asistencia cuando la necesiten. Sin embargo, todas estas formas de comunicación a distancia dependen del acceso a energía eléctrica (OMS, 2020b).

Asimismo, algunas personas que presentan discapacidad múltiple o más severa y son electrodependientes necesitan contar con energía eléctrica para usar apoyos técnicos, por tanto, en esas circunstancias se les debe asegurar el acceso a este servicio mientras dure la emergencia sanitaria y después de ella.

Tanto en la Convención sobre los Derechos de las Personas con Discapacidad, como en el Objetivo 7 de la Agenda 2030 y en la medida prioritaria 77 del Consenso de Montevideo sobre Población y Desarrollo se promueven el desarrollo y el bienestar de las personas de todos los territorios, sin ningún tipo de discriminación, incluido el pleno acceso a servicios sociales básicos. Por tanto, los Estados deben garantizar el cumplimiento de estos derechos durante la emergencia sanitaria y cuando esta haya pasado.

\section{Distribución espacial de la discapacidad y del acceso a los servicios básicos en las ciudades}

El territorio es un espacio físico y social donde se expresan las desigualdades sociodemográficas y la segregación residencial socioeconómica (González, 2017). Esto ha cobrado fuerza durante la crisis sanitaria, social y económica actual, ya que el nivel de contagio y mortalidad a causa del COVID-19, así como las implicancias socioeconómicas de este, han afectado con más intensidad a determinados territorios que a otros

En este sentido, la CEPAL ha planteado que en esta región "el lugar importa": no da lo mismo nacer o vivir en un territorio u otro, puesto que este influye de forma importante en la distribución de las oportunidades de acceder al bienestar (CEPAL, 2010). En varias secciones de este documento se ha constatado que hay asimetrías entre las áreas urbanas y las rurales, y que, en general, en las áreas urbanas hay más servicios básicos, más acceso a las tecnologías de la información, mejor conectividad en materia de transporte y más disponibilidad de servicios de salud

La crisis sanitaria provocada por el COVID-19 ha tenido un fuerte impacto en las áreas urbanas. Sin embargo, si bien hay que esforzarse por controlar el contagio en el ámbito urbano, esto no debe llevar a descuidar las áreas rurales, porque allí las condiciones sanitarias y sociales son más débiles, y la expansión del COVID-19 podría ser devastadora (CEPAL/OPS, 2020).

En América Latina y el Caribe, que es una región muy urbanizada, las metrópolis han sido las más afectadas. Ciudades como São Paulo, Río de Janeiro, Lima, Santiago, Ciudad de México y Buenos Aires lideran las cifras de contagios y defunciones por COVID-19 en sus países.

La gran concentración de población en las ciudades y metrópolis, así como los graves déficits acumulados en el ámbito del saneamiento, el acceso al agua potable y el hacinamiento, inciden en la propagación del virus. Esto se acentúa debido a la dificultad de cumplir el confinamiento en el hogar cuando es imperioso salir a trabajar para conseguir el sustento diario en momentos de crisis económica, y por el hecho de que en ciudades tan concentradas es difícil mantener la distancia física en el transporte y los espacios públicos.

Estos déficits y las dificultades para aplicar las medidas de contención no se distribuyen de manera homogénea en las ciudades, sino que se concentran principalmente en las áreas más pobres y afectan con mayor fuerza a los grupos socioeconómicos más desaventajados.

Sobre la base de los datos que se obtienen de los censos de población es posible analizar los déficits de acceso a los servicios básicos y el hacinamiento en las ciudades y sus componentes, ya que se puede desagregar la información a escalas territoriales menores. En los mapas 1, 2 y 3 se muestra cómo se distribuyen la población con discapacidad,
El acceso a luz eléctrica en los hogares de las personas con discapacidad es imprescindible para que estas puedan conocer la información relativa a la pandemia y acceder a servicios y políticas públicas que las beneficien. 
el acceso al agua potable y los hogares con hacinamiento que tienen personas con discapacidad en divisiones administrativas menores de tres ciudades de la región en que se cuenta con información reciente: Bogotá, Ciudad de Guatemala y Lima.

En el mapa 1 se constata que, en Bogotá, los mayores porcentajes de personas con discapacidad en el área metropolitana se presentan en los municipios Sopó $(5,3 \%)$, Sibaté $(3,9 \%)$, Bogotá $(3,4 \%)$ y Cota $(3,1 \%)$. Los mayores porcentajes de hacinamiento entre los hogares que tienen personas con discapacidad se observan en los municipios de Cota $(15,4 \%)$ y Sibaté $(13,1 \%)$. Entre los municipios que presentan un mayor porcentaje de hogares sin acceso a agua potable dentro de la vivienda destacan Soacha (10,5\%), Cota $(6,8 \%)$ y Sopo $(6,8 \%)$. Los dos últimos también se ubican entre los que presentan mayores porcentajes de personas con discapacidad, por lo que allí se podría presentar un mayor número de contagios entre esas personas y es donde deben redoblarse las medidas de cuidado destinadas a ellas.

Mapa 1

Bogotá: proporción de personas con discapacidad, de hogares donde hay hacinamiento y personas con discapacidad, y de hogares sin acceso a agua potable, por municipio, censo de 2018

(En porcentajes)
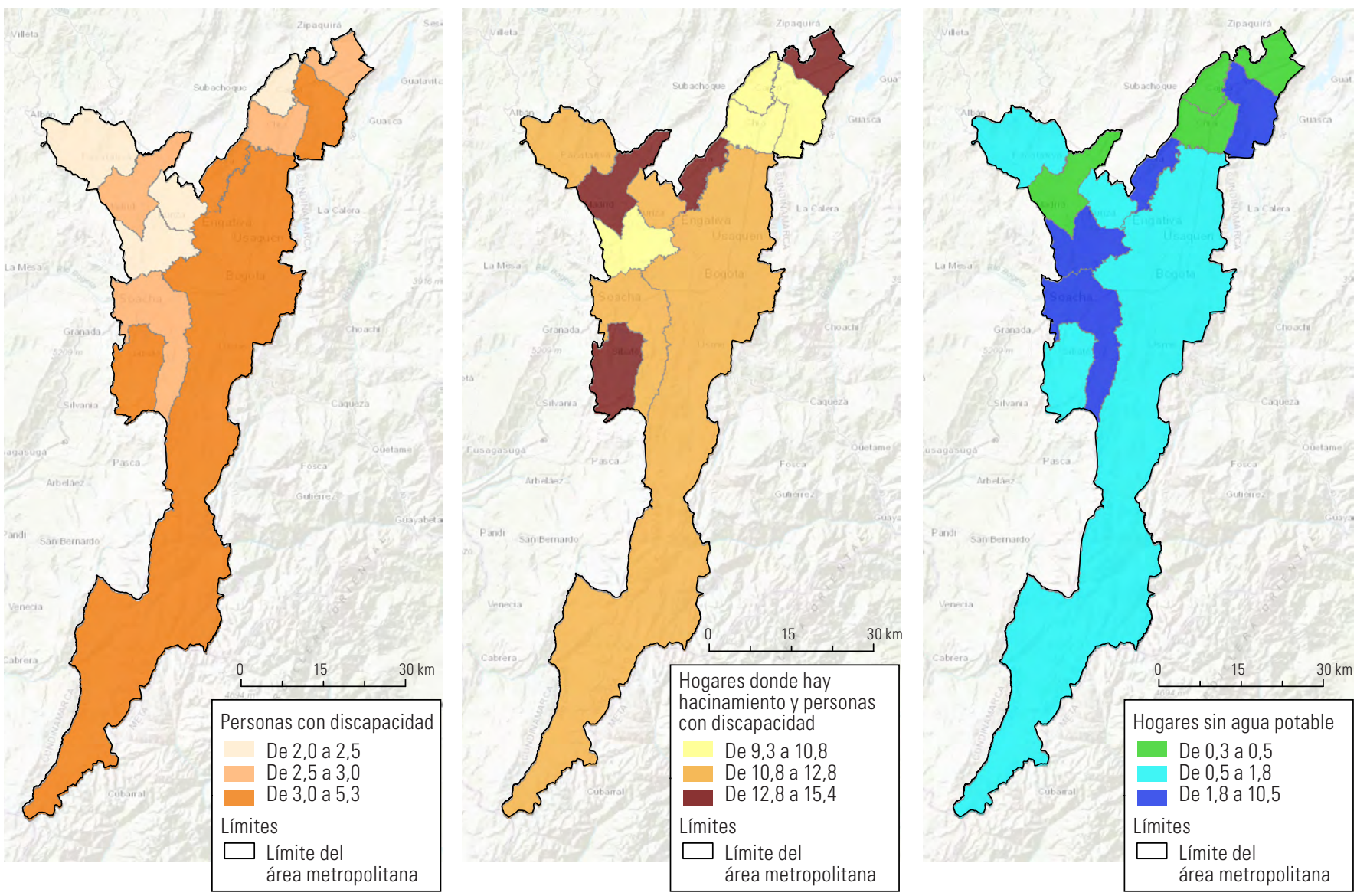

Fuente: Comisión Económica para América Latina y el Caribe (CEPAL), sobre la base de microdatos censales de Colombia procesados con REDATAM; Centro Latinoamericano y Caribeño de Demografía (CELADE)-División de Población de la CEPAL, Distribución Espacial de la Población y Urbanización en América Latina y el Caribe (DEPUALC), 2020 [en línea] https://celade.cepal.org/bdcelade/depualc/.

En el caso de Ciudad de Guatemala, los municipios en que se concentra el mayor porcentaje de personas con discapacidad son Guatemala y San Pedro Sacatepéquez $(3,7 \%)$, San José Pinula (3,3\%), Mixco y Chinautla (3,1\%), y los que presentan la mayor proporción de hogares donde hay hacinamiento y personas con discapacidad son los de San Pedro Sacatepéquez (54,5\%), San Juan Sacatepéquez (46,1\%), Villa Canales (41,1\%) y 
Chinautla (40,5\%) (véase el mapa 2). Por otra parte, los mayores porcentajes de hogares sin acceso a agua potable se encuentran en los municipios de San Juan Sacatepéquez (33,4\%), San Pedro Sacatepéquez (21,2\%), Villa Canales (14,6\%) y San José Pinula (12,2\%). La mayor proporción de personas con discapacidad y los déficits más graves se encuentran en San Pedro Sacatepéquez y San José Pinula, municipios donde hay un alto nivel de pobreza y vulnerabilidad social.

Mapa 2

Ciudad de Guatemala: proporción de personas con discapacidad, de hogares donde hay hacinamiento y personas con discapacidad, y de hogares sin acceso a agua potable, por municipio, censo de 2018

(En porcentajes)

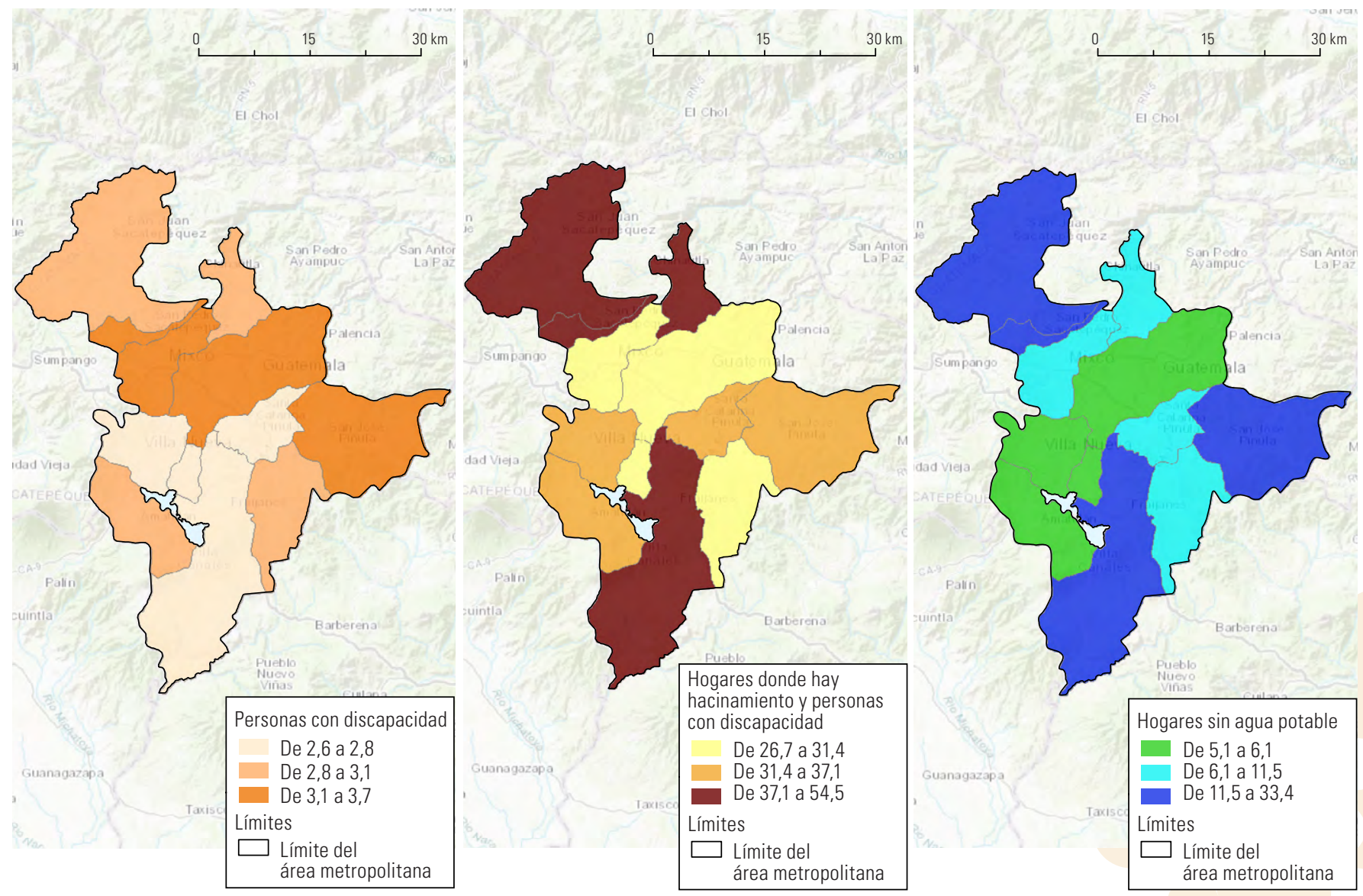

Fuente: Comisión Económica para América Latina y el Caribe (CEPAL), sobre la base de microdatos censales de Guatemala procesados con REDATAM; Centro Latinoamericano y Caribeño de Demografía (CELADE)-División de Población de la CEPAL, Distribución Espacial de la Población y Urbanización en América Latina y el Caribe (DEPUALC), 2020 [en línea] https://celade.cepal.org/bdcelade/depualc/.

Lima ha sido una de las ciudades más golpeadas por la pandemia y 17 de los 53 municipios que conforman esta área metropolitana se ubican entre los que tienen porcentajes más elevados de personas con discapacidad (del 11,6\% al 13,3\%) (véase el mapa 3). Entre los distritos que presentan la mayor proporción de hogares donde hay hacinamiento y personas con discapacidad destacan Santa Eulalia y Pachacamac, donde el porcentaje varía del $21 \%$ al 26\%. La mayor proporción de hogares sin acceso a agua potable dentro de la vivienda se encuentra en 17 distritos del aglomerado, donde el porcentaje va del 40\% al 74\%. Destacan Punta Negra, Punta Hermosa y Cienaguilla, donde más de la mitad de los hogares no tienen acceso a agua potable dentro de la vivienda. Estos indicadores ponen de manifiesto que hay áreas de Lima donde hay déficits urbanos que pueden contribuir a que el virus se propague y surja una mayor cantidad de casos de COVID-19. 


\section{Mapa 3}

Lima: proporción de personas con discapacidad, de hogares donde hay hacinamiento y personas con discapacidad, y de hogares sin acceso a agua potable, por distrito, censo de 2017

(En porcentajes)
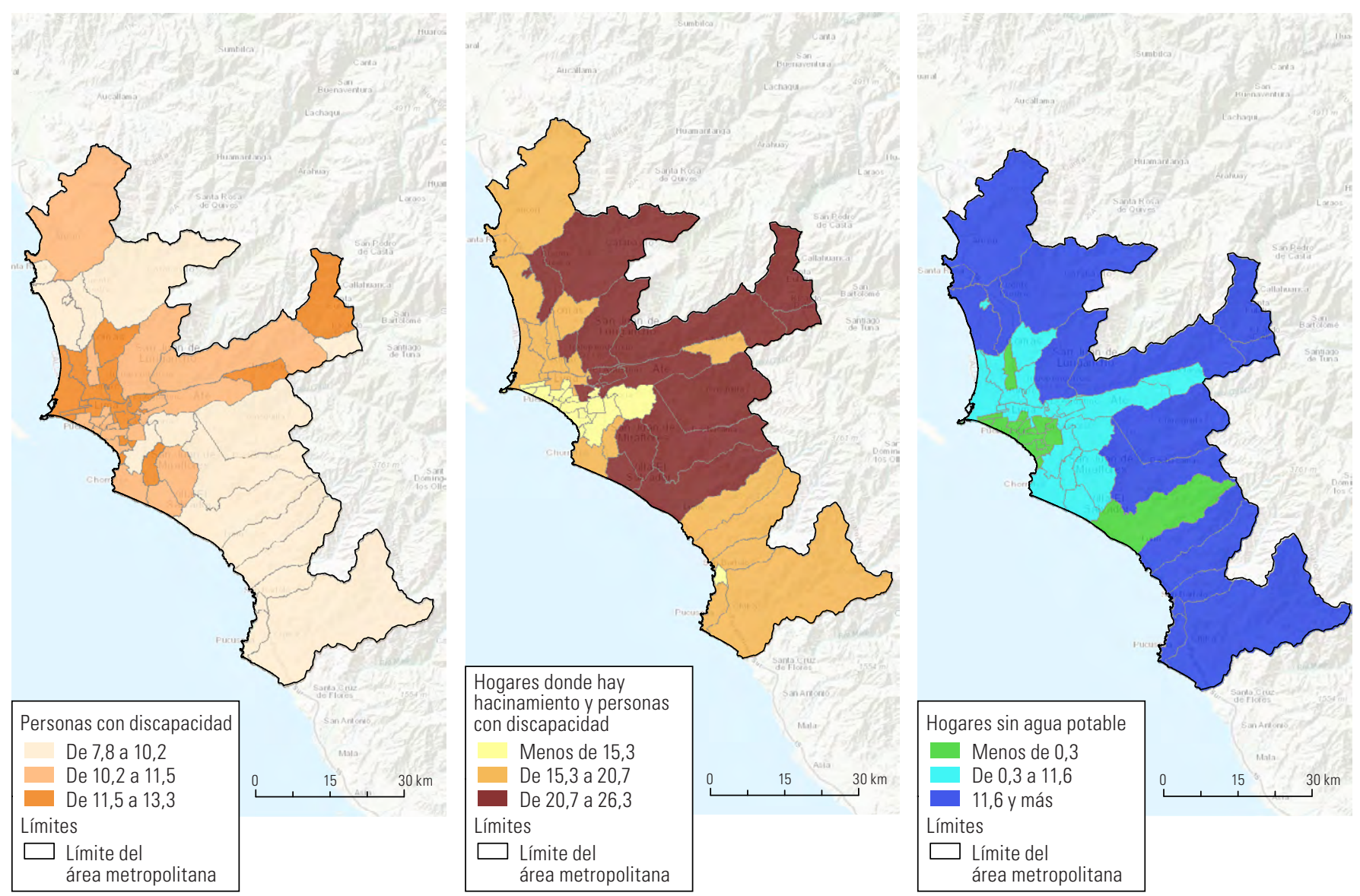

Fuente: Comisión Económica para América Latina y el Caribe (CEPAL), sobre la base de microdatos censales procesados con REDATAM; Centro Latinoamericano y Caribeño de Demografía (CELADE)-División de Población de la CEPAL, Distribución Espacial de la Población y Urbanización en América Latina y el Caribe (DEPUALC), 2020 [en línea] https://celade.cepal.org/bdcelade/depualc/.

El territorio importa: se constata que la pandemia ha tenido un impacto diferente en distintas zonas de las ciudades.
Con los tres casos que se acaban de describir se corrobora que la pandemia ha expuesto profundas desigualdades en cuanto a cómo viven las personas en las ciudades, en particular, las personas con discapacidad. La población que ya se encontraba en situación de vulnerabilidad es la que más ha sufrido con esta crisis (ONU-Hábitat, 2020).

Este análisis también revela la importancia de los gobiernos locales y de que estos coordinen la gestión de la crisis en las ciudades, tanto en lo que respecta a la implementación de medidas durante la pandemia como en lo que atañe a la planificación de acciones a mediano y largo plazo. En este sentido, en una declaración conjunta de la Enviada Especial del Secretario General sobre la Discapacidad y la Accesibilidad y del Coordinador de la Red Cities4All sobre los gobiernos locales y las personas con discapacidad en relación con el COVID-19, se llama a que los gobiernos locales y regionales adquieran un mayor liderazgo, puesto que son ellos los que están en contacto directo con la población de sus respectivos territorios y conocen de cerca las demandas y necesidades que se deben satisfacer durante la emergencia provocada por el COVID-19. Además, ellos son los que están llamados a interactuar con los gobiernos centrales en pro del bienestar de la población (Naciones Unidas, 2020a). En este sentido, en dicha declaración se destaca que esta crisis pone de manifiesto la importancia de "consolidar de manera efectiva la accesibilidad universal de las ciudades y asentamientos humanos, como una forma eficaz para el cumplimiento de los derechos humanos y la superación de la pobreza, contando para esto con el modelo de derechos humanos reconocido en la Convención sobre los Derechos 
de las Personas con Discapacidad de Naciones Unidas, la Agenda 2030 sobre Desarrollo Sostenible, la Nueva Agenda Urbana, el Marco de Sendai para la Reducción del Riesgo de Desastres y la Estrategia de la Red Mundial de Ciudades y Comunidades Amigables con las Personas Mayores de la OMS, teniendo siempre en cuenta la realidad de cada contexto local y las necesidades y propuestas ciudadanas" (Naciones Unidas, 2020a, pág. 3). Esto plantea grandes desafíos a mediano y largo plazo, que suponen repensar las ciudades y metrópolis teniendo en cuenta el Objetivo 11 de la Agenda 2030, en que se propone lograr que las ciudades y los asentamientos humanos sean inclusivos, seguros, resilientes y sostenibles, con transporte, áreas verdes y espacios públicos accesibles, para no dejar a nadie atrás. Esto se relaciona con el Consenso de Montevideo sobre Población y Desarrollo, particularmente con varias medidas prioritarias del capítulo G, que trata sobre la desigualdad territorial, la movilidad espacial y la vulnerabilidad. Allí se destaca la importancia de diseñar y ejecutar planes, políticas y programas e instrumentos de gestión territorial a diferentes escalas subnacionales, urbanas y de sistemas ciudades, sobre la base de los derechos, la sostenibilidad ambiental, la perspectiva de género y la interculturalidad.

\section{Nivel de instrucción y asistencia escolar}

Los niños, niñas, adolescentes y jóvenes con discapacidad y en edad escolar enfrentan diversas barreras de accesibilidad. Hay barreras que son físicas y se relacionan con el transporte y el acceso a las escuelas, pero también hay otras que atañen al presupuesto y al contexto escolar (materiales de aprendizaje, capacitación de profesores y currículos inclusivos). Además, hay barreras actitudinales que los profesores, los compañeros de clase y de escuela, y los padres de los demás estudiantes imponen a diario (CEPAL, 2019d).

Utilizando información de los censos realizados a inicios de la década de 2010, González y Stang (2014) constataron que el porcentaje de asistencia escolar de los niños y niñas de los grupos de 3 a 4 años y de 5 a 11 años era bastante similar entre los que tenían alguna discapacidad y los que no la tenían. En efecto, advirtieron que prácticamente no había brechas entre los niños y niñas con y sin discapacidad, y que algo similar se observaba en el caso de los adolescentes y jóvenes (González y Stang, 2014).

Por una parte, estos antecedentes indican que, cuando la discapacidad no alcanza los grados más elevados, los programas de educación inclusiva permiten que los niños y las niñas con discapacidades puedan realizar sus estudios, sea en centros especializados o en instituciones educacionales mixtas. Con todo, es importante considerar que los niños, niñas, adolescentes y jóvenes con discapacidad que se insertan en la educación formal por lo general lo hacen en escuelas "especiales": la proporción que puede participar en procesos inclusivos de escolarización varía entre los países, e incluso dentro de ellos, lo que quiere decir que estas personas no participan de una escolarización inclusiva. Además, muchos de ellos presentan rezago escolar y, en ocasiones, son mantenidos en la educación formal pasada la edad promedio de egreso.

Los datos censales más recientes de los tres países que se han analizado ponen de relieve una situación similar respecto del acceso de las personas con discapacidad a la enseñanza formal. Si bien el porcentaje de acceso de estas es menor que el de las personas sin discapacidad en los tres países, las brechas no superan los 17, 14 y 5 puntos porcentuales en Guatemala, Colombia y el Perú, respectivamente (véase el gráfico 9). Asimismo, se constata que el acceso de los hombres con discapacidad a los espacios formativos es muy similar al de las mujeres en esa situación. Cuando se comparan las áreas rurales y las urbanas, no obstante, sí se aprecian desigualdades de acceso: en las primeras hay una proporción muy baja de niños, niñas y adolescentes con discapacidad que asiste a la escuela. Uno de los porcentajes más bajos de asistencia escolar es el que se observa en las áreas rurales del Perú, donde solo el $9 \%$ de los niños con discapacidad asiste a la escuela. En las zonas urbanas de ese país, en cambio, la asistencia escolar de esos niños alcanza el 91\%. En Colombia, la brecha entre las áreas urbanas y las rurales es menor, pero también se observa esta asimetría entre el campo y la ciudad: 1 de cada 4 niños con discapacidad asiste a la escuela en las zonas rurales, en tanto que 3 de cada 4 lo hace en las zonas urbanas. En Guatemala la brecha es menor, pero se sigue la misma tendencia: $40 \%$ de los niños con discapacidad de las áreas rurales asiste a la escuela, mientras que, en las urbanas, la proporción llega al 60\%. 
Gráfico 9

Colombia, Guatemala y Perú: proporción de niños, niñas y adolescentes que asisten a la escuela, según situación de discapacidad, sexo y área de residencia, censos de la década de 2010

(En porcentajes)

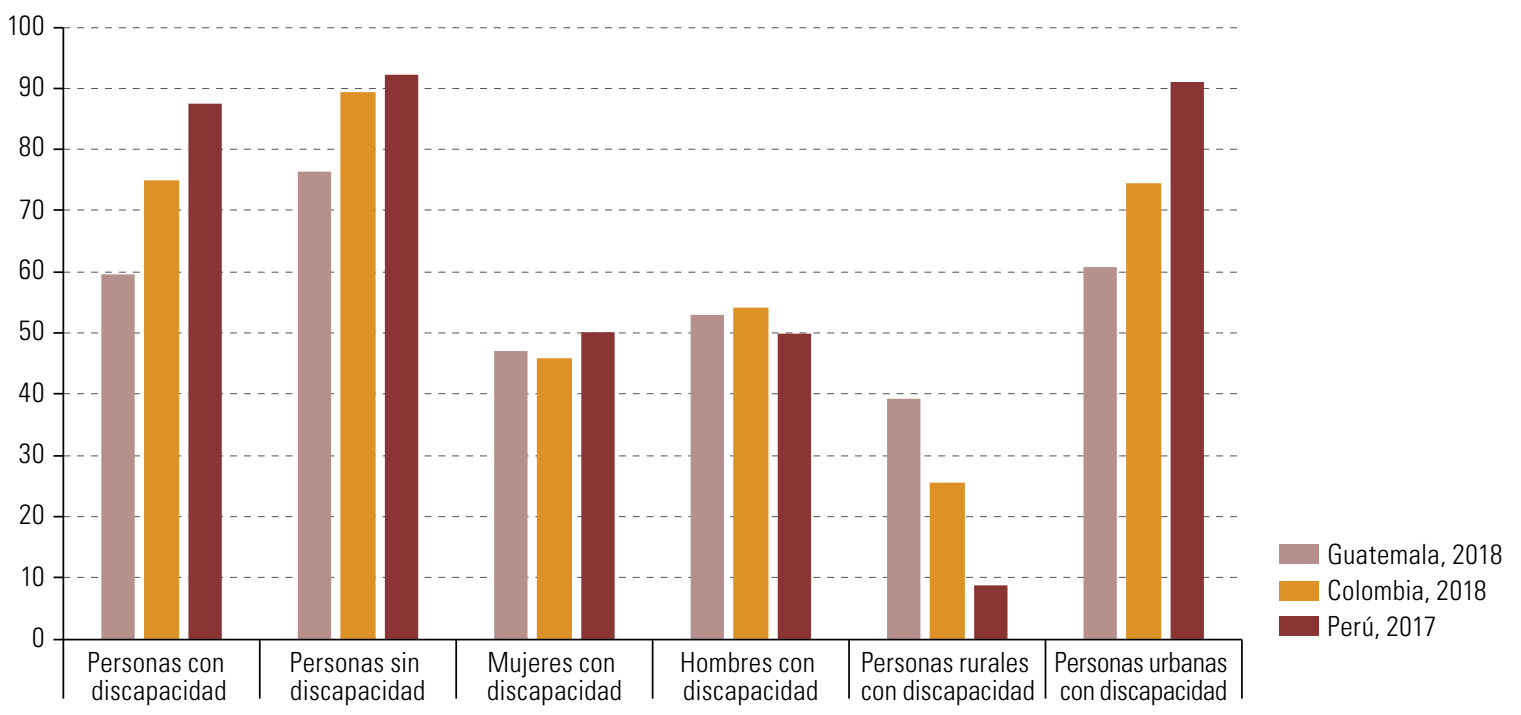

Fuente: Comisión Económica para América Latina y el Caribe (CEPAL), sobre la base de microdatos censales de los países correspondientes procesados con REDATAM.

Cuando el COVID-19 se instaló en la región, una de las primeras medidas que se tomaron en la mayoría de los países fue la suspensión de las clases presenciales en todos los niveles. De esta forma, con mayor o menor rapidez se dio inicio a modalidades de aprendizaje a distancia, en una diversidad de formatos y plataformas (CEPAL/UNESCO, 2020). El cierre de las escuelas también ha significado la interrupción del suministro de servicios de alimentación y nutrición a la población estudiantil, particularmente en los sectores más vulnerables, que además han sido los más afectados durante la pandemia. Las escuelas prestan otros servicios que son de gran apoyo para los estudiantes, servicios a los que estos no han tenido acceso durante el cierre, por ejemplo, la entrega de anticonceptivos, la prestación de servicios de salud mental y de apoyo en el aprendizaje inclusivo, o la organización de actividades recreativas (CEPAL/UNESCO, 2020).

Si bien el cierre de las escuelas ha afectado a todos los estudiantes en general, en el caso de los que tienen discapacidad y de sus familias se advierten complejidades específicas. La interrupción de las actividades presenciales tendrá un efecto significativo en el aprendizaje de los estudiantes con discapacidad, pues el apoyo de los equipos multidisciplinarios que guían sus actividades escolares no estará presente. Además, las rutinas de trabajo son esenciales para tener buenos resultados en materia de enseñanza, y esto no es fácil de implementar en el hogar (CEPAL/UNESCO, 2020).

Si bien se han realizado todos los esfuerzos para implementar actividades de aprendizaje en modalidades virtuales, ya sean sincrónicas o asincrónicas, en el caso de los estudiantes con discapacidad esto ha sido un doble desafío, ya que las plataformas de enseñanza deben adaptarse al tipo de discapacidad que presentan (visual, auditiva o física, entre otras), y eso no se ha logrado en todos los casos. Además, como se mostrará en la próxima sección, en los hogares que tienen personas con discapacidad hay brechas de acceso a las computadoras y a Internet. Por tanto, aunque se han diseñado planes para promover el uso de los dispositivos digitales en los sistemas educativos, los estudiantes con discapacidad han tenido muchas más dificultades para acceder a ellos (CEPAL, 2020a; CEPAL/UNESCO, 2020; Ullmann y otros, 2018). 
Es importante considerar que, dadas las barreras que los estudiantes con discapacidad pueden enfrentar para acceder a la enseñanza virtual, es posible que haya un riesgo de desvinculación educativa y deserción escolar, particularmente en el caso de los estudiantes que pertenecen a los grupos más vulnerables durante esta pandemia y crisis sanitaria, social y económica (CEPAL/UNESCO, 2020).

Se deben poner en práctica medidas de corto y mediano plazo para evitar que la interrupción de la asistencia a clases sea definitiva. En un estudio reciente de CEPAL/UNESCO (2020) se recomienda promover la continuidad del vínculo con los niños, niñas y adolescentes que tienen más probabilidades de desvincularse, y agotar los medios posibles para favorecer la continuidad del aprendizaje. Esto adquiere mayor relevancia en el caso de los estudiantes con discapacidad, y las barreras que estos pueden encontrar deben reducirse al máximo, intentando evaluar caso a caso la necesidad de apoyo para dar continuidad a los estudios y realizar las adaptaciones necesarias. Es muy importante que estos estudiantes no pierdan el vínculo con sus ámbitos educativos formales, para que no queden excluidos debido a la ausencia de apoyos técnicos y ajustes razonables. A mediano plazo, se recomienda crear mecanismos para asegurar que no exista un perjuicio pedagógico ni en cuanto a la promoción de los estudiantes que no logren continuar con el aprendizaje en este período. Para esto se recomienda "articular medidas como la eliminación de la repetición, establecer mecanismos de continuidad curricular flexibles junto con estrategias de apoyo para la recuperación y aceleración de aprendizajes" (CEPAL/UNESCO, 2020, pág. 15). En el caso de los estudiantes con discapacidad, estas medidas son necesarias para que el aprendizaje continúe, considerando que el proceso educativo debe adecuarse a sus necesidades y llevarse a cabo a un ritmo al que ellos puedan adaptarse. Pero a mediano y largo plazo también surge otro desafío: evitar que, con el objetivo de simplificar la accesibilidad, se deje a los estudiantes con discapacidad recluidos en sus casas recibiendo solo educación a distancia. La mayor riqueza de los lugares educativos inclusivos son las relaciones que se generan entre todos los estudiantes, y los vínculos entre ellos, sus profesores y la comunidad educativa: esto no solo mejora la condición del estudiante con discapacidad, sino que enriquece las relaciones de todos.

En las medidas y acciones que se implementen a corto y mediano plazo se deben considerar la protección y la garantía de los derechos de la infancia, así como los derechos de los niños y niñas con discapacidad y los de protección social de las familias que tienen hijos con discapacidad. En tal sentido, en el artículo 24 de la Convención sobre los Derechos de las Personas con Discapacidad, que se refiere a la educación, se establece que los "Estados Partes asegurarán un sistema de educación inclusivo a todos los niveles, así como la enseñanza a lo largo de la vida", y se dice que una de las razones para hacer esto es "hacer posible que las personas con discapacidad participen de manera efectiva en una sociedad libre" (Naciones Unidas, 2006, pág. 15). Por tanto, al hacer efectivo este derecho que se establece en la Convención, los Estados partes se asegurarán de que la discapacidad no sea motivo para que las personas queden excluidas del sistema general de educación, ni para que los niños y las niñas queden excluidos de la enseñanza primaria gratuita y obligatoria, ni de la enseñanza secundaria. También garantizarán que se hagan ajustes razonables en función de las necesidades individuales, y que, en el marco del sistema general de educación, se preste el apoyo necesario a las personas con discapacidad para facilitar su formación efectiva. Los Estados parte facilitarán la adopción de medidas de apoyo personalizadas y efectivas en entornos que fomenten al máximo el desarrollo académico y social, de conformidad con el objetivo de la plena inclusión (Naciones Unidas, 2006, pág. 15). Por otra parte, en el Objetivo 4 de la Agenda 2030, que se refiere a garantizar una educación inclusiva y equitativa de calidad, y a promover oportunidades de aprendizaje permanente para todos, se establecen diversas metas en que se considera a las personas con discapacidad y se destaca el acceso a espacios físicos escolares inclusivos y la elaboración de currículos educativos para todos. Una preocupación en este sentido es que los estudiantes con discapacidad no se queden atrás ni fuera de los sistemas educativos debido a esta pandemia mundial, pues esto podría poner en peligro los avances que tanto ha costado conseguir en materia de educación inclusiva e integral.
El rezago en el nivel de instrucción y la menor asistencia escolar de los estudiantes con discapacidad pueden acentuarse en el contexto de crisis humanitaria si no se implementan acciones específicas destinadas a ellos. 


\section{Acceso a las tecnologías de la información y las comunicaciones y su uso}

Durante la crisis sanitaria provocada por el COVID-19 se ha recomendado que los servicios públicos y las personas con discapacidad dispongan de tecnologías de asistencia y de la información y las comunicaciones que favorezcan la comunicación y la autonomía de las personas en situaciones de emergencia, por ejemplo, videochats para usar intérpretes cuando se presten servicios médicos, aplicaciones celulares que permitan detectar contagios, indicar la ubicación y llamar a emergencias, programas que describan el entorno a las personas ciegas, y programas para leer etiquetas, entre otros (OEA, 2020, pág. 33). El objetivo de esto es disminuir las brechas de acceso digital a la información sobre la pandemia y durante ella, pues, en instancias de distanciamiento físico y confinamiento en los hogares, el acceso a las tecnologías de la información y las comunicaciones (TIC) ha cobrado una importancia aún mayor, sobre todo porque esas tecnologías pueden ser una herramienta fundamental para limitar el impacto negativo sobre las personas con discapacidad y sus familias (CEPAL, 2020a).

A inicios de la década de 2010, los datos censales ya ponían de manifiesto que el acceso a las TIC era un indicador indirecto de pobreza y desigualdad. Esto se debía a que dicho acceso era menor en las áreas rurales que en las urbanas, y entre los grupos más pobres, las personas mayores y las personas con discapacidad respecto de la población en general (CEPAL, 2012). En un estudio de la OMS se indicaba que la proporción de personas con discapacidad que usaban TIC era significativamente menor que la de las personas sin discapacidad, y que, en algunos casos, era posible que las primeras incluso no pudieran acceder a productos y servicios tan básicos como el teléfono, la televisión o Internet (OMS, 2011, pág. 10). Esta situación no ha cambiado mucho en la década presente y las brechas más bien se han agudizado en esta situación de emergencia: de ahí la importancia de fortalecer el acceso a las tecnologías, especialmente desde el punto de vista económico (CEPAL, 2020a).

En los tres países con datos censales más recientes se observa que existe una brecha entre las personas con y sin discapacidad en lo que respecta a las TIC. En el gráfico 10 se presenta el porcentaje de personas sin acceso a Internet en el hogar según condición de discapacidad y área de residencia. Destaca el caso de Guatemala, que presenta los mayores porcentajes de población sin acceso, tanto entre las personas con discapacidad como entre las personas sin discapacidad. En el Perú, el 70\% de la población no tiene acceso a Internet en el hogar y, en Colombia, la cifra es más baja (50\%). En los tres países las personas sin discapacidad tienen más acceso a Internet, aunque esa brecha es mucho más evidente en Colombia. Pese a que el inicio de la década de 2020 está muy cerca, sigue habiendo una brecha entre las zonas urbanas y las rurales en cuanto al acceso a Internet: el porcentaje de personas con acceso a ella en estas últimas es muy bajo en los tres países. En las zonas urbanas, el porcentaje de población sin acceso disminuye, aunque sigue siendo mayor entre las personas con discapacidad.

El porcentaje de población sin acceso a un computador es relativamente menor, aunque sigue siendo alto: en Guatemala, asciende a un 79\% y, en el Perú, a un 63\% (véase el gráfico 11). Hay brechas bien marcadas entre las áreas urbanas y las rurales, sobre todo en el Perú. Además, el porcentaje de personas con discapacidad que no tienen acceso a un computador es mayor que el de las personas sin discapacidad: en Guatemala, esa cifra asciende al 82\% y, en el Perú, al 65\%. El porcentaje supera el 94\% en las áreas rurales de ambos países, y desciende al $73,3 \%$ y al $59 \%$ en las áreas urbanas de Guatemala y el Perú, respectivamente. Estos datos evidencian que las personas con discapacidad en su mayoría no tienen acceso a un computador en sus hogares. Si bien en otros países de la región la penetración de estos bienes en el hogar es más alta, persistirían las brechas entre las personas con y sin discapacidad, y entre las áreas urbanas y rurales. 


\section{Gráfico 10}

Colombia, Guatemala y Perú: proporción de población sin acceso a Internet en el hogar, según condición de discapacidad y área de residencia, censos de la década de 2010 (En porcentajes)

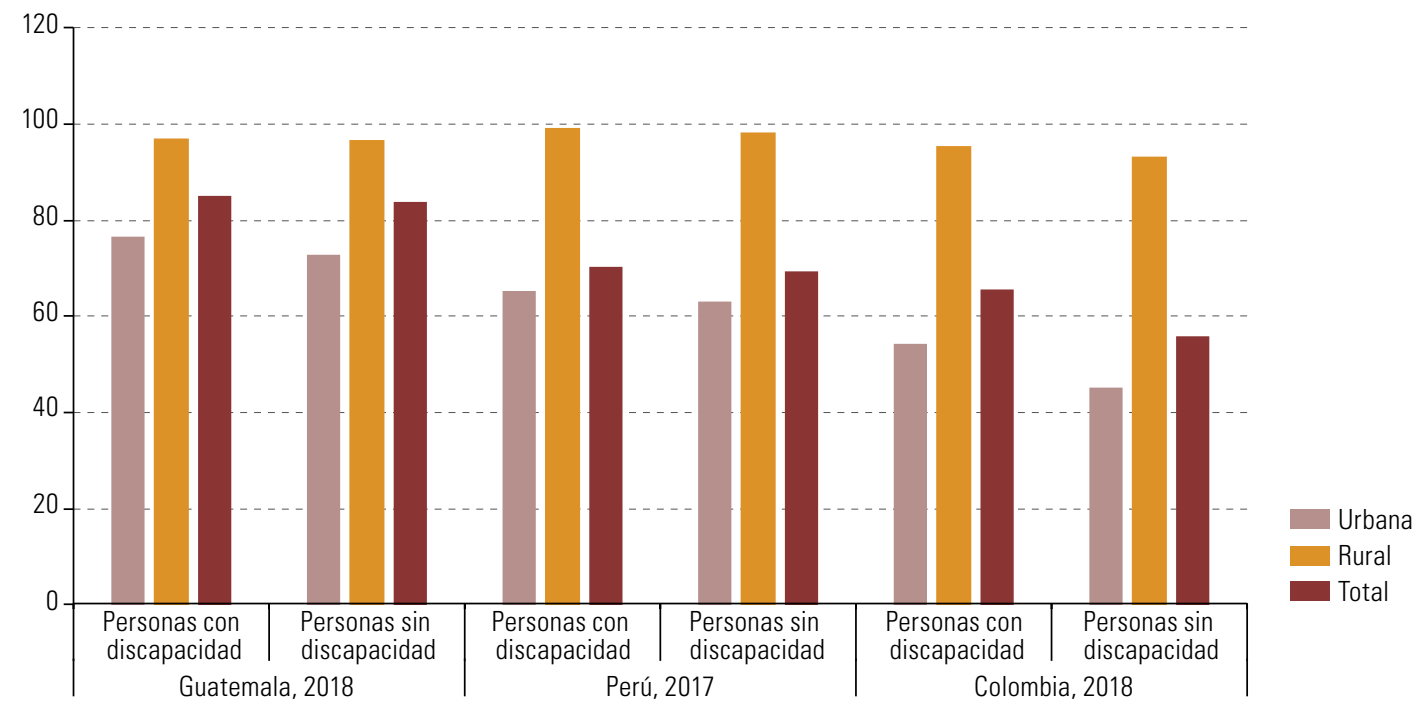

Fuente: Comisión Económica para América Latina y el Caribe (CEPAL), sobre la base de microdatos censales de los países correspondientes procesados con REDATAM.

\section{Gráfico 11}

Guatemala y Perú: proporción de población que no tiene acceso a un computador en el hogar, según condición de discapacidad y área de residencia,

censos de la década de 2010

(En porcentajes)

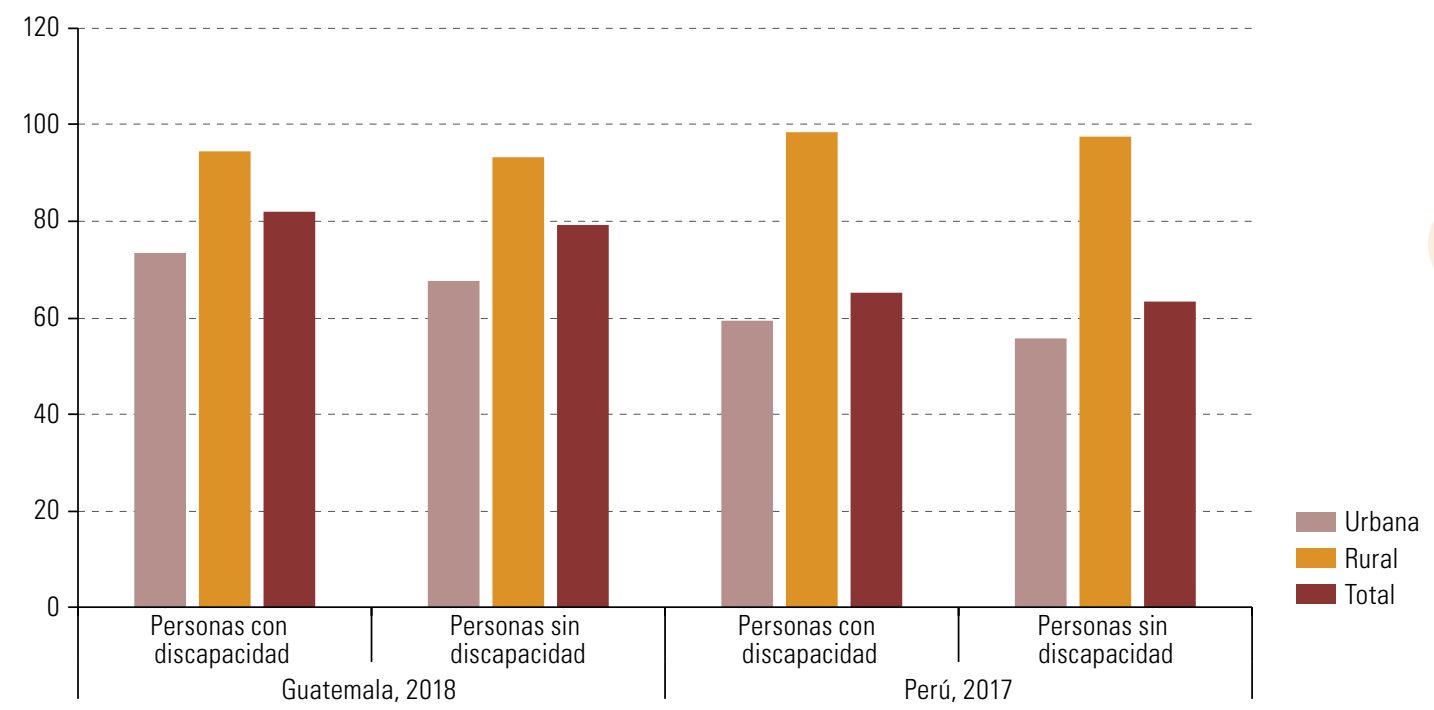

Fuente: Comisión Económica para América Latina y el Caribe (CEPAL), sobre la base de microdatos censales de los países correspondientes procesados con REDATAM. 
El celular tiene una mayor penetración en los hogares tanto de Guatemala como del Perú. Alrededor del 37\% de la población guatemalteca no tiene acceso a un celular, porcentaje que aumenta al $56 \%$ en el caso de las personas con discapacidad (véase el gráfico 12). En el Perú el porcentaje disminuye a un 15\% en el total de la población y a un 18\% entre las personas con discapacidad. En general, en las áreas rurales hay un mayor porcentaje de población sin acceso a celular, tendencia que se aprecia en la mayoría de los países de la región.

Gráfico 12

Guatemala y Perú: proporción de población sin acceso a celular en el hogar, según condición de discapacidad y área de residencia, censos de la década de 2010

(En porcentajes)

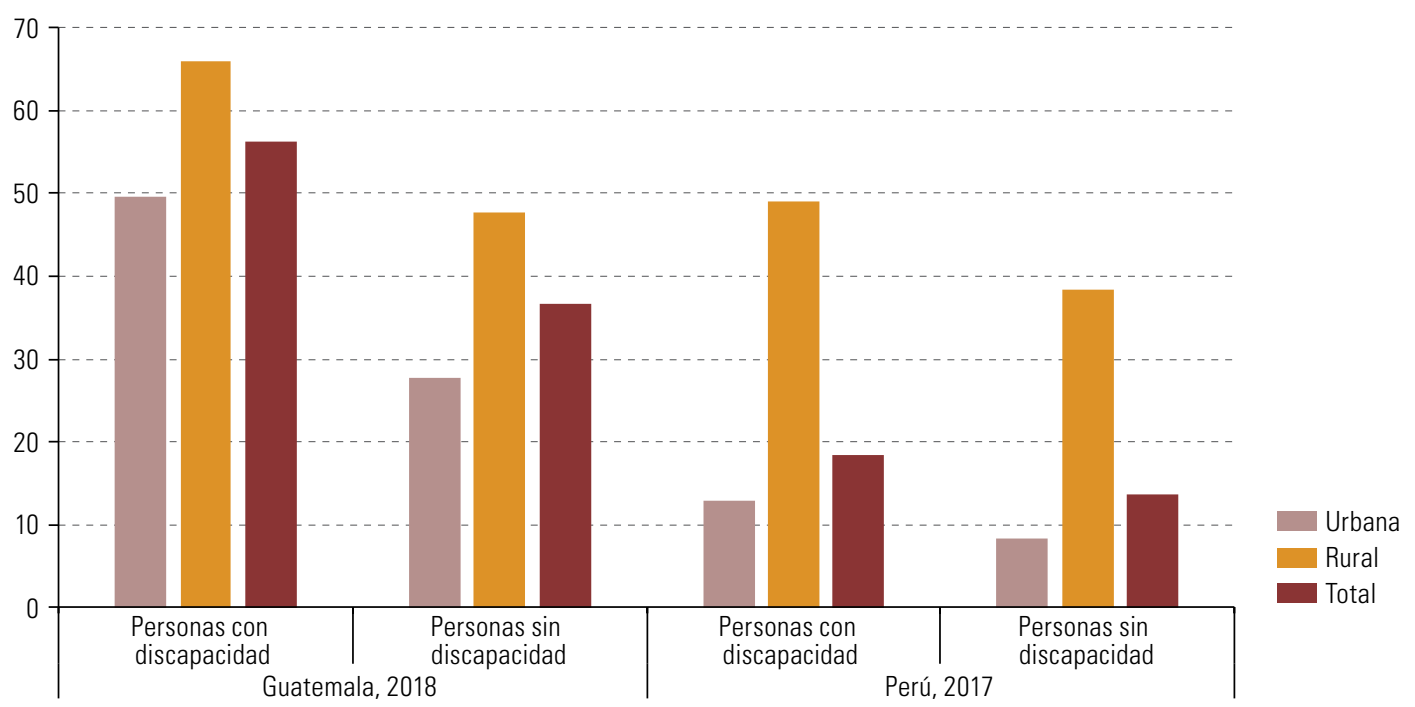

Fuente: Comisión Económica para América Latina y el Caribe (CEPAL), sobre la base de microdatos censales de los países correspondientes procesados con REDATAM.

El acceso a las tecnologías de la información y las comunicaciones (TIC) y su uso brindan la oportunidad de acceder a la información y disminuir el impacto negativo del distanciamiento físico y el confinamiento.
Estas asimetrías de acceso a las TIC muestran claramente que la tenencia de estas tecnologías predomina en las zonas urbanas y, por cierto, se concentra más entre las personas sin discapacidad.

En contextos de pandemia y confinamiento es muy importante ampliar el acceso a las TIC, particularmente en las áreas rurales y entre las personas con discapacidad. Sin embargo, también se debe considerar que las personas con discapacidad enfrentan barreras específicas respecto al uso de las TIC, según el tipo de discapacidad. Esto significa que los porcentajes de acceso que se han descrito no muestran la medida real en que las personas con discapacidad usan estas tecnologías.

En algunos estudios en que se ha indagado sobre este tema se menciona que las personas ciegas o con visión disminuida enfrentan barreras a la hora de usar los servicios visuales, fundamentalmente cuando se brindan contenidos e indicaciones que aparecen en la pantalla del computador, el teléfono móvil o la tableta; por tanto, en estos casos es necesario utilizar una interfaz que no sea la convencional, pues esta constituye un gran impedimento para que estas personas puedan acceder a Internet. En cuanto a las personas sordas o con limitaciones de audición, las principales barreras se refieren a la utilización de contenidos y a la prestación de servicios basados en la voz, así como a la capacidad de comunicarse con otras personas a través de las telecomunicaciones de voz. En el caso de las personas con discapacidad física o movilidad reducida, si bien las barreras que encuentran difieren en función del grado de severidad de la discapacidad que presenten, dichas barreras suelen estar relacionadas con la utilización de interfaces que requieren manipulación precisa, como el ratón y el teclado del computador, los botones 
del teléfono o la pantalla de los teléfonos táctiles. Por tanto, no basta con apoyar el acceso a las TIC solo en términos económicos, sino que se deben crear aplicaciones que permitan lograr un acceso inclusivo a ellas, considerando los distintos tipos de discapacidad. Esto permitiría que las personas con discapacidad pudieran usar las TIC que hubiera en sus hogares

En los países donde hay escasa penetración de las TIC en los hogares, sobre todo en los de las personas con discapacidad, también es útil considerar la televisión y la radio como dispositivos que pueden brindar información relevante durante esta emergencia. Por cierto, los canales de televisión deben incluir lenguaje de señas y subtitulados para que esta información sea inclusiva. Es importante tener esto en cuenta, pues, en general, la penetración de la televisión y la radio es elevada en los hogares de los países de la región.

\section{Inserción laboral}

Antes de la crisis provocada por la pandemia de COVID-19 en nuestra región, los datos indicaban que las tasas de desempleo eran más altas entre las personas con discapacidad, y que estas tenían más probabilidades de no ser económicamente activas que las personas sin discapacidad. Si tenían trabajo, era más probable que tuvieran empleos mal remunerados, informales e inestables, con limitadas perspectivas profesionales (CEPAL, 2019d).

En un informe reciente titulado "Personas con discapacidad ante la enfermedad por coronavirus (COVID-19) en América Latina y el Caribe: situación y orientaciones", se indica que el vínculo de las personas con discapacidad de la región con el mercado laboral es tenue, y que, cuando estas personas participan en el mercado laboral, lo hacen sobre todo en el sector de los servicios y en el empleo informal. Por tanto, es previsible que esta población se vea especialmente afectada por el escenario desfavorable del mercado laboral durante la crisis y el período de recuperación (CEPAL, 2020a).

En este documento se ha comentado que las personas con discapacidad tienen más probabilidades de tener problemas de salud que aumentan el riesgo de contraer COVID-19, y se han señalado las razones por las que esto ocurre. Además, la sobrerrepresentación de las personas con discapacidad entre las personas pobres y en la economía informal aumenta el riesgo de contagio. Estos riesgos se acentúan entre las mujeres, las personas mayores y la población indígena con discapacidad (Naciones Unidas 2020a). Las medidas adoptadas para prevenir el COVID-19 pueden crear nuevas barreras para las personas con discapacidad; por tanto, los riesgos deben abordarse de una manera que proteja a estas personas del contagio, pero a la vez les permita mantener su trabajo e ingresos (OIT, 2020).

Los datos de los censos del Perú y Guatemala se pueden utilizar para obtener una idea aproximada del porcentaje de personas con discapacidad que trabajan y para saber en qué categoría de ocupación se desempeñan. La proporción de personas con discapacidad que trabajan es pequeña. En efecto, menos de un tercio de ellas se desempeña en alguna actividad remunerada: el $27 \%$ en Guatemala y el 31\% en el Perú.

La categoría ocupacional se puede utilizar como indicador indirecto para analizar las relaciones de trabajo, la autoridad, el riesgo económico y la precariedad laboral de las personas con discapacidad que trabajan. Esta información se presenta en el gráfico 13, donde se constata que, independientemente de la edad, las personas con discapacidad se desempeñan sobre todo en las categorías de trabajo por cuenta propia y de empleado u obrero: alrededor del $80 \%$ de las personas con discapacidad que trabajan en Guatemala y del $90 \%$ de las que trabajan en el Perú se ubican en estas dos categorías. La proporción de empleados y obreros es mayor entre los menores de 30 años, mientras que la de trabajadores por cuenta propia se va incrementando a medida que aumenta la edad. Entre un 20\% y un 30\% de los menores de 18 años, por su parte, realizan actividades de apoyo en negocios familiares.

También existen diferencias entre las áreas urbanas y las rurales, pues hay un mayor porcentaje de personas con discapacidad que trabajan como empleados u obreros en las áreas urbanas del Perú y Guatemala, mientras que, en las áreas rurales, se desempeñan mayoritariamente como trabajadores por cuenta propia. 
Gráfico 13

Guatemala y Perú: distribución de las categorías ocupacionales según la edad de las personas con discapacidad que trabajan, censos de la década de 2010

(En porcentajes)

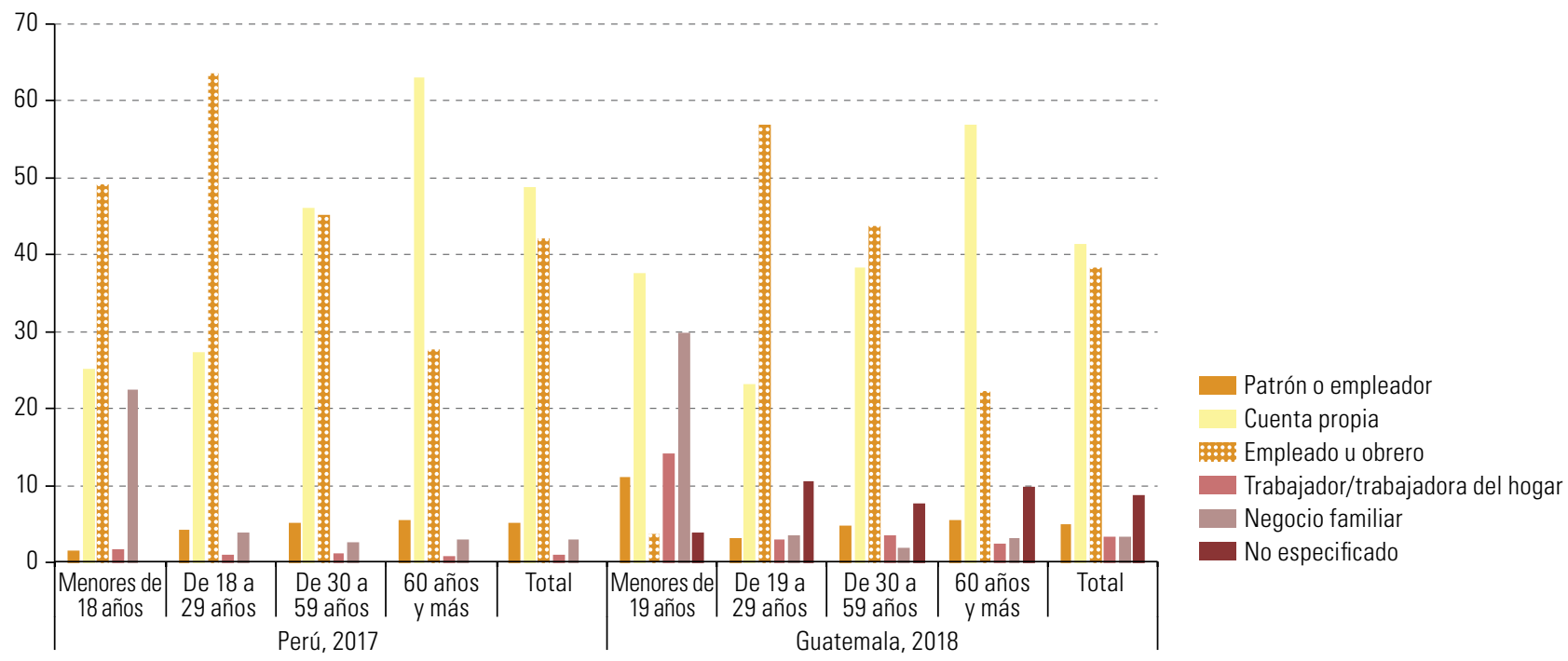

Fuente: Comisión Económica para América Latina y el Caribe (CEPAL), sobre la base de microdatos censales de los países correspondientes procesados con REDATAM.

En lo que respecta a la inserción laboral de las personas con discapacidad, hay problemas de acceso, ausencia de ajustes razonables, discriminación y persistencia de estereotipos negativos, todo lo cual se acentúa durante la crisis sanitaria.
La precarización laboral de las personas con discapacidad, que ya era alta, se acentúa frente a la crisis provocada por el COVID-19. Esto se debe sobre todo a que se ha constatado una reducción de las horas de trabajo, una caída de los salarios y, por cierto, un aumento de los despidos en el trabajo formal. Para que las personas con discapacidad puedan continuar trabajando durante la pandemia, los empleadores deben hacer los ajustes que correspondan en los espacios de trabajo u ofrecer la posibilidad de teletrabajar, además de garantizar que la información sobre los riesgos que el COVID-19 supone para la salud se proporcione a los trabajadores de manera accesible (OIT, 2020). Para esto es muy importante que el contenido digital sea accesible y, cuando sea necesario, que se utilicen lenguaje de señas y formatos de reunión que también lo sean. Estas garantías no han sido fáciles de implementar y, en muchas ocasiones, ha sido más sencillo optar porque las personas con discapacidad se queden confinadas en sus hogares y esperen a que la pandemia pase o a que aparezca una vacuna que las proteja. Por tanto, aunque no se cuenta con cifras, las organizaciones de la sociedad civil que se dedican a las personas con discapacidad en la región han informado que el desempleo ha aumentado entre estas últimas ${ }^{5}$.

Por otra parte, la situación de las personas con discapacidad que trabajan por cuenta propia o en la economía informal es particularmente difícil. Se constata que el empleo ha caído debido al distanciamiento y a la prohibición de circular (CEPAL/OIT, 2020). Esto ha afectado sobre todo a los trabajos que suponen un riesgo alto y medio-alto de contagio: entre los primeros se encuentran, por ejemplo, el comercio, los servicios de comidas y la reparación de vehículos, y, entre los segundos, el transporte y el almacenamiento, la información y las comunicaciones, el entretenimiento y la recreación, y otros servicios. Los trabajadores que se dedican a esas actividades necesitan recibir apoyo para mantener sus medios de vida y tomar las precauciones adecuadas. Los trabajadores con discapacidad se encuentran en una situación vulnerable en la economía informal, en particular con respecto a las medidas adoptadas para mitigar la propagación del coronavirus (OIT y otros, 2020).

\footnotetext{
Entre los foros virtuales en que se ha tratado el tema destacan los siguientes: Comisión Económica para América Latina y el Caribe (CEPAL), "Seminario web: El Impacto Multidimensional de la Crisis por la COVID-19 en las Personas con Discapacidad" [en línea] https://www.cepal.org/es/eventos/seminario-web-impacto-multidimensionalla-crisis-la-covid-19-personas-discapacidad; Red Latinoamericana de Organizaciones no Gubernamentales de Personas con Discapacidad y sus Familias (RIADIS), "Estadísticas sobre Discapacidad para Políticas Públicas Eficaces y Respuestas Inclusivas durante la Pandemia por el COVID-19" [en línea] https://www.facebook.com/ RIADISORG/videos/2542436402753004, y Secretaría General Iberoamericana (SEGIB), "Ciclo de webinars para incluir a las personas con discapacidad en la respuesta a la crisis por el COVID-19" [en línea] https://www.segib. org/ciclo-de-webinars-para-incluir-a-las-personas-con-discapacidad-en-la-respuesta-a-la-crisis-por-el-covid-19/.
} 
En el artículo 27 de la Convención sobre los Derechos de las Personas con Discapacidad se aborda el tema del trabajo y el empleo, y se indica que los "Estados Partes reconocen el derecho de las personas con discapacidad a trabajar, en igualdad de condiciones con las demás; ello incluye el derecho a tener la oportunidad de ganarse la vida mediante un trabajo libremente elegido o aceptado en un mercado y un entorno laborales que sean abiertos, inclusivos y accesibles a las personas con discapacidad" (Naciones Unidas, 2006, pág. 17). Por tanto, los Estados deben crear las condiciones para que las personas con discapacidad que trabajan puedan seguir realizando estas actividades con los mayores resguardos posibles. Ello supone elaborar protocolos y diversas acciones en que se aborden estos temas junto con los actores pertinentes del mundo del trabajo, para garantizar la protección contra el COVID-19. Esto se podría lograr mediante la aplicación de medidas accesibles de salud y seguridad en el trabajo, el otorgamiento de protección social que permitiera proporcionar una asistencia inmediata, la consulta a las personas con discapacidad, la participación significativa de estas y el establecimiento de mecanismos financieros inclusivos (OIT, 2020).

Ahora más que nunca cobran fuerza la Agenda 2030 y los Objetivos de Desarrollo Sostenible (ODS), particularmente el Objetivo 8, que se refiere a promover el crecimiento económico sostenido, inclusivo y sostenible, el empleo pleno y productivo, y el trabajo decente para todos. Esos principios se deben aplicar para no dejar atrás a las personas con discapacidad y para que estas no queden fuera del trabajo decente. Se debe apuntar a que todas las mujeres y los hombres, incluidos los jóvenes y las personas con discapacidad, alcancen el empleo pleno y productivo, y el trabajo decente. En el contexto actual es necesario monitorear el cumplimiento de la meta 8.8 del Objetivo mencionado anteriormente, que se refiere a proteger los derechos laborales y a promover un entorno de trabajo seguro y sin riesgos para todos los trabajadores, incluidos los migrantes $y$, en particular, las mujeres migrantes y las personas con empleos precarios, entre ellas las personas con discapacidad. A los efectos de llevar a cabo ese monitoreo es preciso redoblar los esfuerzos para obtener datos y estadísticas actualizados sobre las personas con discapacidad y el empleo.

\section{Recomendaciones sobre las acciones de política pública}

En la región no ha habido una respuesta homogénea a la hora de enfrentar la pandemia: cada país ha respondido en tiempos y maneras distintos. Por consiguiente, la cantidad de infectados y las tasas de mortalidad difieren entre los países, y varios de ellos lideran las estadísticas mundiales en ambas variables. Actualmente, en la región hay una gran incertidumbre respecto de cómo seguirá evolucionando esta pandemia y de cuáles serán las consecuencias económicas a mediano y largo plazo. La economía de los países ya se ha resentido, y la población también ha estado expuesta a diversos efectos sociales y psicológicos

Esta pandemia ha revelado las enormes desigualdades que las personas con discapacidad enfrentan en diferentes ámbitos, algunos de los cuales se presentan en este documento. Un aspecto que reviste gran importancia es el de la invisibilidad estadística: si no se cuenta con información respecto de las personas con discapacidad, es muy difícil poner en práctica acciones de política pública que las favorezcan. Esto ha quedado en evidencia en este documento, donde se ha señalado que en los países de la región no siempre se cuenta con información actualizada y comparable, obtenida en cumplimiento de las recomendaciones internacionales, que permita hacer una intervención rápida en situaciones de crisis y desastres.

En los diferentes informes que la CEPAL ha elaborado en relación con el COVID-19 se destaca que "la pandemia del COVID-19 tiene fuertes efectos en el ámbito de la salud y profundas implicaciones sobre el crecimiento económico y el desarrollo social" (CEPAL, 2020d, pág. 1). La pandemia ha golpeado más fuerte a los grupos más vulnerables de la población, entre los que destacan las personas con discapacidad, que ya se encontraban en una situación de desventaja social y económica.

Entre las principales acciones que se han implementado en diferentes sectores de algunos países de la región para apoyar a las personas con discapacidad durante la crisis provocada por el COVID-19 se destacan las siguientes: 
- Se han diseñado sistemas para asegurar que la información relevante se proporcione en formatos accesibles, considerando la utilización de intérpretes de lenguaje de señas y subtitulado, entre otros.

- Los centros de salud familiar a escala local han distribuido información sintética y clara dirigida a las personas con discapacidad psicosocial.

- Las organizaciones de la sociedad civil han puesto en práctica medidas de precaución atendiendo a la particularidad de las discapacidades, por ejemplo, han elaborado mascarillas transparentes para la población sorda y mascarillas en que aparece un texto para avisar que la persona tiene una discapacidad.

- En algunos países de la región en que se han implementado instancias de confinamiento total o cuarentena estricta se ha definido un permiso especial para que las niñas y niños del espectro autista puedan salir al espacio público.

- A las personas de apoyo y las cuidadoras formales se las ha eximido de cumplir las restricciones de desplazamiento y distanciamiento físico para que puedan asistir a las personas con discapacidad.

- Se han creado redes de apoyo comunitario y se han reclutado voluntarios que apoyan a las personas con discapacidad y a las personas mayores con sus compras de alimentos y de otro tipo.

- Se han asignado horarios de apertura específicos para que las personas con discapacidad y sus asistentes personales puedan hacer las compras esenciales.

- En algunos países, las personas que reciben prestaciones por discapacidad recibirán un monto adicional debido a la crisis provocada por el COVID-19.

- Se han elaborado recomendaciones dirigidas a los profesores sobre cómo apoyar la educación de los niños y las niñas con discapacidad que realizan actividades escolares desde casa y sobre cómo respaldar de la mejor manera posible su proceso educativo.

Es muy importante que en los países se dé una respuesta inclusiva a la pandemia, tanto durante la cuarentena, asegurando el acceso pleno a los suministros necesarios para la vida y la salud, como en las medidas que se adopten después de ella, garantizando el ejercicio efectivo de derechos como la educación inclusiva de calidad y la inclusión laboral. En este sentido, los principios de no discriminación, igualdad de oportunidades y accesibilidad establecidos en la Convención sobre los Derechos de las Personas con Discapacidad son un pilar fundamental en la gestión de la emergencia sanitaria, tanto durante el transcurso de esta como en la rehabilitación posterior, sobre todo en lo que se refiere a los servicios de salud.

En este sentido, se pueden enumerar algunas recomendaciones específicas que resultan del panorama trazado en este documento y que se han señalado en distintas instancias internacionales con el objetivo de que en los países se hagan esfuerzos para mejorar la situación de las personas con discapacidad:

- Los instrumentos acordados a escala internacional, discutidos ampliamente y en proceso de implementación, como la Convención sobre los Derechos de las Personas con Discapacidad, el Consenso de Montevideo sobre Población y Desarrollo, y la Agenda 2030 para el Desarrollo Sostenible, son herramientas de referencia para priorizar las medidas que tengan por objeto garantizar que la pandemia cause el menor impacto posible en las personas con discapacidad y que se respeten sus derechos.

- Es urgente promover la investigación sobre el impacto del COVID-19 en la salud de las personas con discapacidad. Para ello se debe hacer lo siguiente: garantizar que se priorice la realización de pruebas diagnósticas a las personas con discapacidad que presenten síntomas; identificar y eliminar las barreras que obstaculizan el tratamiento, lo que incluye disponer entornos accesibles en los hospitales y las instalaciones de prueba y cuarentena, y destinar recursos financieros a dichas investigaciones.

- La información y las comunicaciones sobre la salud se deben elaborar y difundir en modos, medios y formatos accesibles, y se debe involucrar activamente a las personas con discapacidad y a sus organizaciones en la elaboración de una respuesta a la pandemia que se base en los derechos y permita incluir a las personas con discapacidad en toda su diversidad. 
- Respecto de las medidas de protección social, es fundamental asegurar los ingresos y el consumo de los hogares donde hay personas con discapacidad mediante ayuda financiera destinada a esas personas cuando no tengan ningún ingreso. También se debe garantizar que los niños, niñas, adolescentes y jóvenes con discapacidad accedan a los servicios básicos, a la vivienda, a una alimentación adecuada y a la educación.

- Se debe asegurar que las personas con discapacidad tengan acceso a servicios de apoyo para llevar una vida segura, saludable e independiente. Si las cuidadoras informales han dejado de trabajar en el empleo formal para destinar todo su tiempo al apoyo de algún pariente con discapacidad, se deben poner en marcha programas de asistencia financiera para cubrir esa falta de ingreso en el hogar.

- En el ámbito laboral se recomienda implementar todas las medidas necesarias de protección, ajustes específicos y entornos accesibles para garantizar la seguridad de las personas con discapacidad que siguen trabajando durante la pandemia. En los casos en que sea necesario, los empleadores de personas con discapacidad deben darles prioridad para que trabajen desde el hogar o para que se les conceda licencia con goce de sueldo.

- Se deben reabrir las instituciones de enseñanza en condiciones de seguridad. Mientras esto no ocurra, puede existir una oportunidad para que los sistemas educativos nacionales se transformen en sistemas equitativos e inclusivos. Con ese fin se debe garantizar el acceso a Internet para el aprendizaje a distancia y asegurar que los programas informáticos sean accesibles para las personas con discapacidad, incluso mediante el suministro de dispositivos de asistencia y la puesta en práctica de ajustes razonables. Es necesario proporcionar orientación, capacitación y apoyo a los docentes en materia de educación inclusiva mediante el aprendizaje a distancia, y diseñar materiales accesibles y adaptados a los estudiantes con discapacidad, para apoyar ese tipo de aprendizaje.

- Las personas con discapacidad tienen derecho a participar de forma plena y efectiva en las decisiones que afectan sus vidas. Poniendo en práctica el lema "nada sobre nosotros sin nosotros", acuñado por quienes impulsaron la Convención sobre los Derechos de las Personas con Discapacidad, es necesario garantizar una respuesta inclusiva. En todas las etapas de la respuesta, desde la planificación y el diseño hasta la ejecución y la supervisión, se debe consultar a las personas con discapacidad y sus organizaciones, y ellas deben participar activamente. Esto ayudará a lograr la inclusión inmediata, permitirá que todas las medidas relacionadas con el COVID-19 beneficien a las personas con discapacidad, y contribuirá al desarrollo y a la recuperación a más largo plazo.

En todos los temas que se trataron en este documento se constató que hay una ausencia o un importante déficit de datos e información sobre las personas con discapacidad. En necesario contar con esta información para comprender las distintas formas en que las personas con discapacidad se ven afectadas por el COVID-19, y para comprobar que sean incluidas en todas las fases de la respuesta y la recuperación. Es indispensable disponer de sistemas robustos de recolección y difusión de datos que aseguren el desglose a nivel subnacional por discapacidad, edad, sexo y causa de muerte. Estos datos deberían reunirse utilizando métodos reconocidos internacionalmente y considerando las recomendaciones de la División de Estadística de las Naciones Unidas, así como del Grupo de Washington sobre Estadísticas de la Discapacidad y la OMS. Estas recomendaciones deberían reflejarse en las distintas fuentes de datos: los censos de población y vivienda, las encuestas específicas de discapacidad y los registros administrativos, particularmente los registros de personas con discapacidad. La información recopilada a largo plazo debe desagregarse por género, edad, origen étnico y condición migratoria, ya que las interseccionalidades que se dan entre estos grupos vulnerables acentúan los riesgos y pueden crear nuevas barreras para las personas con discapacidad. Por tanto, es muy importante contar con esta información para diseñar políticas sociales basadas en derechos dirigidas a este grupo poblacional. 


\section{Bibliografía}

ACNUDH (Oficina del Alto Comisionado de las Naciones Unidas para los Derechos Humanos) (2020), "COVID-19 y los derechos de las personas con discapacidad: directrices", Ginebra, abril [en línea] https://www.ohchr.org/Documents/Issues/ Disability/COVID-19_and_The_Rights_of_Persons_with_Disabilities_SP.pdf.

Arriagada, I. (2007), "Familias latinoamericanas: cambiantes, diversas y desiguales", Papeles de Población, vol. 13, No 53, Toluca, Universidad Autónoma del Estado de México (UAEM)

Bautista, J. (2013), "El derecho humano al agua y al saneamiento frente a los Objetivos de Desarrollo del Milenio (ODM)", Documentos de Proyectos (LCM.536), Santiago, Comisión Económica para América Latina y el Caribe (CEPAL), abril.

CDC (Centro para el Control y la Prevención de Enfermedades) (2020), "Personas con discapacidad", Atlanta, 11 de septiembre [en línea] https://espanol.cdc.gov/ coronavirus/2019-ncov/need-extra-precautions/people-with-disabilities.html.

CEPAL (Comisión Económica para América Latina y el Caribe) (2020a), "Personas con discapacidad ante la enfermedad por coronavirus (COVID-19) en América Latina y el Caribe: situación y orientaciones", Informe COVID-19, Santiago, abril.

_ (2020b), "Dimensionar los efectos del COVID-19 para pensar en la reactivación", Informe Especial COVID-19, No 2, Santiago, abril.

_ (2020c), "La pandemia del COVID-19 profundiza la crisis de los cuidados en América Latina y el Caribe", Informe COVID-19, Santiago, abril.

_ (2020d), "El desafío social en tiempos del COVID-19", Informe Especial COVID-19, No 3, Santiago, mayo

(2019a), "Aspectos conceptuales de los censos de población y vivienda: desafíos para la definición de contenidos incluyentes en la ronda 2020", serie Seminarios y Conferencias, No 94 (LC/TS.2019/67), Santiago.

_ (2019b), Primer informe regional sobre la implementación del Consenso de Montevideo sobre Población y Desarrollo (LC/CRPD.3/6), Santiago.

_ (2019c), Informe de avance cuatrienal sobre el progreso y los desafíos regionales de la Agenda 2030 para el Desarrollo Sostenible en América Latina y el Caribe (LC/FDS.3/3/Rev.1), Santiago.

(2019d), Panorama Social de América Latina, 2018 (LC/PUB.2019/3-P), Santiago. (2018a), Panorama Social de América Latina, 2017 (LC/PUB.2018/1-P), Santiago

(2018b), Hacia una agenda regional de desarrollo social inclusivo: bases y propuesta inicial (LC/MDS.2/2), Santiago.

(2016), La matriz de la desigualdad social en América Latina (LC/G.2690(MDS.1/2)), Santiago.

_ (2014), Informe regional sobre la medición de la discapacidad: una mirada a los procedimientos de medición de la discapacidad en América Latina y el Caribe (LC/L.3860(CE.13/3)), Santiago

(2013a), Panorama Social de América Latina, 2012 (LC/G.2557-P), Santiago.

(2013b), Consenso de Montevideo sobre Población y Desarrollo (LC/L.3697), Santiago.

(2012), Población, territorio y desarrollo sostenible (LC/L.3474(CEP.2/3), Santiago.

(2010), La hora de la igualdad: brechas por cerrar, caminos por abrir (LC/G.2432 (SES.33/3)), Santiago.

CEPAL/OIT (Comisión Económica para América Latina y el Caribe/Organización Internacional del Trabajo) (2020), "El trabajo en tiempos de pandemia: desafíos frente a la enfermedad por coronavirus (COVID-19)", Coyuntura Laboral en América Latina y el Caribe, No 22 (LC/TS.2020/46), Santiago.

CEPAL/ONU-Mujeres (Comisión Económica para América Latina y el Caribe/Entidad de las Naciones Unidas para la Igualdad de Género y el Empoderamiento de las Mujeres) (2020), Cuidados en América Latina y el Caribe en tiempos de COVID-19: hacia sistemas integrales para fortalecer la respuesta y la recuperación, Santiago, agosto. 
CEPAL/OPS (Comisión Económica para América Latina y el Caribe/Organización Panamericana de la Salud) (2020), "Salud y economía: una convergencia necesaria para enfrentar el COVID-19 y retomar la senda hacia el desarrollo sostenible en América Latina y el Caribe", Informe COVID-19 CEPAL-OPS, Santiago, julio.

CEPAL/UNESCO (Comisión Económica para América Latina y el Caribe/Organización de las Naciones Unidas para la Educación, la Ciencia y la Cultura) (2020), "La educación en tiempos de la pandemia de COVID-19", Informe COVID-19 CEPAL-UNESCO, Santiago, agosto.

González, D. (2017), "Desigualdades socio demográficas, segregación residencial socioeconómica y su expresión territorial", Indicadores no monetarios de pobreza: avances y desafíos para su medición, P. Villatoro (comp.), serie Seminarios y Conferencias, No 87 (LC/TS.2017/149), Santiago, Comisión Económica para América Latina y el Caribe (CEPAL), diciembre.

González, D. y M. Stang (2014), "Las personas con discapacidad en América Latina a 20 años de los consensos de El Cairo: la necesidad de información para políticas y programas", Notas de Población, vol. 41, No 99 (LC/G.2628-P), Santiago, Comisión Económica para América Latina y el Caribe (CEPAL), diciembre.

Grupo de Washington sobre Estadísticas de la Discapacidad (2017), The Washington Group Short Set on Functioning: Question Specifications, Washington, D.C., 23 de octubre [en línea] https://www.washingtongroup-disability.com/fileadmin/uploads/ wg/Documents/Events/17/WG-Document-4-The-Washington-Group-Short-Set-onFunctioning-Question-Specifications.pdf.

(2009), Understanding and Interpreting Disability as Measured using the WG Short Set of Questions, Washington, D.C., 20 de abril [en línea] http://www.cdc.gov/nchs/ data/washington_group/meeting8/interpreting_disability.pdf.

Meléndez, R. (2019), "Las políticas públicas en materia de discapacidad en América Latina y su garantía de acceso a una educación inclusiva de calidad", Revista Actualidades Investigativas en Educación, vol. 19, No 2, San José, Universidad de Costa Rica (UCR).

Naciones Unidas (2020a), "Declaración conjunta: gobiernos locales y personas con discapacidad en relación al COVID-19", Nueva York, 5 de mayo [en línea] https:// www.un.org/development/desa/disabilities/wp-content/uploads/sites/15/2020/05/ Decl-Gobiernos-locales-y-pcd-Covid-19-5mayo-F.pdf.

(2020b), "Declaración conjunta: mujeres y niñas con discapacidad y mujeres mayores en relación a la pandemia COVID-19", Nueva York, 28 de abril [en línea] https://www. un.org/development/desa/disabilities/wp-content/uploads/sites/15/2020/04/ decl-mujeres-ni\%C3\%B1as-mujeres-mayores-COVID-19.pdf.

(2020c), "Documento de políticas: la COVID-19 en un mundo urbano", Nueva York, julio [en línea] https://www.un.org/sites/un2.un.org/files/covid-19_in_an_urban_ world_spanish.pdf.

(2020d), "Informe de políticas: una respuesta a la COVID-19 inclusiva de la discapacidad", Nueva York [en línea] https://www.un.org/sites/un2.un.org/files/ spanish_disability_brief.pdf.

(2020e), "Declaración conjunta: el derecho a la vida de las personas con discapacidad y personas mayores infectadas por el COVID-19", Nueva York, abril [en línea] https:// www.un.org/development/desa/disabilities/wp-content/uploads/sites/15/2020/04/ Versi\%C3\%B3n2-Decl-Est\%C3\%A1ndar-Bioet-Dpcd-ES2Oabril.pdf.

(2020f), "17 Objetivos para transformar nuestro mundo", Nueva York [en línea] https://www.un.org/sustainabledevelopment/es/.

(2009), Realización de los Objetivos de Desarrollo del Milenio para las personas con discapacidad mediante la aplicación del Programa de Acción Mundial para las Personas con Discapacidad y la Convención sobre los derechos de las personas con discapacidad. Informe del Secretario General (A/64/180), Nueva York.

(2006), Convención sobre los Derechos de las Personas con Discapacidad(A/RES/61/106), Nueva York.

OEA (Organización de los Estados Americanos) (2020), Guía práctica de respuestas inclusivas y con enfoque de derechos ante el COVID-19 en las Américas, Washington, D.C. 
OIT (Organización Internacional del Trabajo) (2020), "Nadie se queda atrás, ni ahora, ni nunca: personas con discapacidad en la réplica al COVID-19", Ginebra, abril [en línea] https://www.ilo.org/wcmsp5/groups/public/---ed_emp/---ifp_skills/ documents/publication/wcms_741305.pdf.

OIT y otros (Organización Internacional del Trabajo y otros) (2020), "Respuesta inclusiva de protección social a la crisis del COVID-19: para las personas con discapacidad", Ginebra [en línea] https://www.social-protection.org/gimi/gess/RessourcePDF. action?id=56039.

OMS (Organización Mundial de la Salud) (2020a), Fortalecimiento de la preparación para la COVID-19 en las ciudades y otros entornos urbanos: orientaciones provisionales para las autoridades locales, Ginebra.

_ (2020b), Consideraciones relativas a la discapacidad durante el brote de COVID-19, Ginebra.

(2011), Informe Mundial sobre la Discapacidad: Resumen, Ginebra.

ONU-Hábitat (Programa de las Naciones Unidas para los Asentamientos Humanos) (2020), "COVID-19: mensajes clave", Nairobi [en línea] https://unhabitat.org/sites/ default/files/2020/05/covid19_key_messages_sp.pdf.

OPS (Organización Panamericana de la Salud) (2020), "Consideraciones relativas a la discapacidad durante el brote de COVID-19", Ginebra [en línea] https://iris.paho. org/bitstream/handle/10665.2/52026/OPSNMHCOVID19200009_spa.pdf.

Pérez, A. (2016), "Impacto de la discapacidad en el núcleo familiar", Navarra, Universidad Pública de Navarra (UPNA) [en línea] https://academica-e.unavarra.es/bitstream/ handle/2454/23449/TFG_AMAIA\%2OPEREZ\%20AYESA.pdf.

Stang, M. (2011), "Las personas con discapacidad en América Latina: del reconocimiento jurídico a la desigualdad real", serie Población y Desarrollo, No 103 (LC/L.3315-P), Santiago, Comisión Económica para América Latina y el Caribe (CEPAL), abril.

Ullmann, H. y otros (2018), "Information and communications technologies for the inclusion and empowerment of persons with disabilities in Latin America and the Caribbean", Documentos de Proyectos (LC/TS.2018/48), Santiago, Comisión Económica para América Latina y el Caribe (CEPAL), octubre.

Este documento forma parte de un conjunto de informes elaborados por la Comisión Económica para América Latina y el Caribe (CEPAL) sobre la evolución y los efectos de la pandemia de COVID-19 en la región. Fue elaborado por el Centro Latinoamericano y Caribeño de Demografía (CELADE)-División de Población de la CEPAL, dirigido por Paulo Saad, bajo la coordinación general de Alicia Bárcena, Secretaria Ejecutiva de la CEPAL.

La publicación de este documento se realiza gracias a la cooperación del Gobierno de Alemania a través del Ministerio Federal de Cooperación Económica y Desarrollo (BMZ) y de la Deutsche Gesellschaft für Internationale Zusammenarbeit (GIZ).

Los límites y los nombres que figuran en los mapas incluidos en este documento no implican su apoyo o aceptación oficial por las Naciones Unidas.

Copyright (C) Naciones Unidas, 2021 